VOX PATRUM 22 (2002) t. 42-43

\title{
PATRYSTYKA W CZASOPISMACH 2002 ROKU
}

1. ACTA ANTIQUA 42 (2001) nr 1-4:

Z. Visy - „Amicitia et invidia”. Diokletians Beziehungen zu seinen Mitregenten 173-180; G. Kendeffy - Augustine on Divine Ideas as Epistemological Criteria 181-193; G. Heidl - The Initial State of Man in Augustine's "De genesi contra Manichaeos» 195-202; I.M. Bugár - How to Prove the Existence of a Supreme Being? 203-215; B. Löfstedt - Drei neue Patristica 217222; I. Borzsak - Die Antihelden in der frühchristlichen Hymnendichtung 223-228.

2. ACTA ORIENTALIA 55 (2002) nr 1-4:

J.Ch. Ducene - Une description arabe du $4^{\text {ème }} / 10^{\text {ème }}$ siècle du mont Sinaï 319-326.

3. ACTA UNIVERSITATIS WRATISLAVIENSIS. HISTORIA (2002) nr 158:

M. Pawlak - Niewolnicy prywatni w rzymskiej Afryce w okresie wczesnego Cesarstwa 1-147.

4. ADAMANTIUS 8 (2002):

T. Böhm - Origenes - Theologe und (Neu-) Platoniker? Oder: Wem soll man mißtrauen - Eusebius oder Porphyrius? 7-23; E. Cattaneo - Alcune proposte di correzione al testo del "De decretis" di Atanasio 24-32; S. Taranto Esiste una „doppia creazione” delle origini in Gregorio Nisseno? 33-56; F. Bucchi - Il "Commento alla Lettera a Tito» di Gerolamo 57-82; M.O. Boulnois - La resurrection des corps selon Cyrille d'Alexandrie: une critique de la doctrine origénienne? 83-113; A. Passoni Dell'Acqua - I LXX nella Biblioteca di Alessandria 114-126; A. Kamesar - Writing Commentaries on the Works of Philo: Some Reflections 127-134; Ch. Markschies Origenes in Berlin und Heidelberg 135-145; A. Bausi - New Egyptian Texts in Ethiopia 146-151; B. Studer - Kritische Beobachtungen zum "Neunizänismus" der modernen deutschen Dogmengeschichte 152-159; D. Alekna Alexandrie en Lituanie: „potius sero...” 160-166; C. Burini - Mario Naldini: per una „paideia cristiana” 167-173. 
5. AEVUM 76 (2002) nr 1-3:

I. Ramelli - „Protector Christianorum” (Tert. «Apol.»V 4): il „miracolo della pioggia" e la lettera di Marco Aurelio al Senato 101-112; C. Dognini L'Indiké di Arriano: tre studi a confronto 113-122; S. Saracino - La politica culturale dell'imperatore Giuliano attraverso il "Cod. Th. "XIII 3, 5 el' Ep." 61, 123-141; G. Folliet - „Inquillina” vel „concellaria” (Exode 3, 22): deux leçons de la "Vetus Latina" confrontées par Augustin 143-149; A. MartanoScolli e glosse allo "Scudo di Eracle" dal manoscritto ambrosiano C 222 Inf., 151-200; F. Quox - Ritualité et chant sacré dans l' "Ordo Romanus primus"

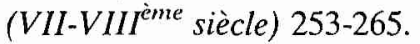

6. ALETHEIA (2002) nr 21-22:

(Nr 21) M. Jerome - De Jérusalem à Rome. Jalons historiques et bibliques pour une théologie de l'economie divine dans le cadre du christianisme naissant 111-118.

7. ALPHA OMEGA 4 (2002) nr 1-3:

D. Corry - „Fides intelligentiam sibi adsumit”. Some reflections on faith and reason from Hilary of Poitiers' "De Trinitate» 3-30; E. McNamara - Christology, Liturgy, Spirituality: Reflections on the Interpretations of their Historical Relationship 137-158; F. Scarafoni - Experiencia y autoridad en el "Contra académicos» de san Agustín 159-186.

8. THE AMERICAN BENEDICTINE REVIEW 53 (2002) nr 1-4:

The «Admonitio ad filium spiritualem», introduction and translation $\mathrm{R}$. Rivers - H. Hagan 121-146; Serving the Lord: Chapter Six of the Greek Systematic Apophtegmata, „Concerning Voluntary Poverty”, transl. T. Vivian - A.N. Athanassakis 193-209; H. Feiss - Review Article: The Substance of the Ephemeral: Clothing in the Benedictine Tradition 243-263; F. ClarkSaint Benedict's Biography and the Turning Tide of Controversy 305-325; G.J. Crites - John Cassian and the Development of Early Irish Christianity: A Study of the State of the Literature 377-399; M. Del Cogliano-Porcarius of Lérins and His "Counsels». A Monastic Study: Part 1, 400-425; T.G. Kardong - The Healing of Shame in the Rule of Benedict 453-474.

9. ANÁ MNESIS 12 (2002) nr 1-2:

(Nr 1) P. Argárate - Hermenéutica y exégesis de los Padres de la Iglesia 2538; F. Soto-Hay - Textos sobre los ritos de iniciación en algunos escritos gnósticos 39-58; (nr 2) F. Soto-Hay - Melitón de Sardes. Una aproximación a su exégesis 37-49.

10. ANALECTA BOLLANDIANA 120 (2002) nr 1-2:

P. Meyvaert - Discovering the Calendar (annalis libellus) attached to Bede's own copy of De temporum ratione 5-64; M. Detoraki - La métaphrase du Martyre de S. Aréthas (BHG 166y). Entre les Actes anciens (BHG 166) et Syméon Métaphraste (BHG 167) 72-100; X. Lequeux - Jean Mauropous, Jean Mauropodès et le culte de saint Baras au monastère du Prod- 
rome de Pétra à Constantinople 101-109; C. Pasini - Un sinassario palinsesto italogreco nel codice Ambrosiano F 106 Sup. 110-134; F. Leroy - Une source africaine oubliée du "Missale Gothicum» pour la preface des saints Innocents: le sermon pseudoaugustinien Caillau II, 79, 135-140; Une nouvelle collection bollandienne: "Tabularium hagiographicum», 151-153; A. Berger - Die alten Viten des heiligen Mamas von Kaisareia. Mit einer Edition der Vita BHG 1019, 241-310; P. ó Riain - A Northumbrian Phase in the Formation of the Hieronymian Martyrology. The Evidence of the Martyrology of Tallaght 311-363; N. Everett - The "Liber de apparitione S. Michaelis in Monte Gargano" and the Hagiography of Dispossession 364-391; J. van der Straeten - Catalogues de manuscrits latins. Inventaire hagiographique (Vingt-cinquième serie) 404-437.

11. ANCIENT PHILOSOPHY 22 (2002) nr 1-2:

G. Reydams-Schils - Philo of Alexandria on Stoic and Platonist PsychoPhysiology: The Socratic Higher Ground 125-147.

12. ANNALI DI STORIA DELL'ESEGESI 19 (2002) nr 1-2:

A. Monaci - Sacrificio e perdono dei pecatti in Origene 43-58; A. CamplaniM. Zambon - Il sacrificio come problema in alcune correnti filosofiche di età imperiale 59-99; M. Simonetti - Eusebio sui sacrifici pagani e giudaici 101110, E. Prinzivalli - Il sacrificio in Girolamo 111-126; G. Lettieri - „Sacrificium civitas est". Sacrifici pagani e sarcificio cristiano nel "De civitate Dei» di Agostino 127-166; E. Mazza - Il tema del sacrificio nelle mistagogie della fine del quarto secolo 167-199; E. Cavalcanti - Il linguaggio relativo al sacrificio nei «Sermoni» di Leone Magno 201-203; M. Zerbini - Selvaggina e cereali: elementi del sacrificio romano 225-235; A. Saggioro - Il sacrificio pagano nella reazione al cristianesimo: Giuliano e Macrobio 237-254.

13. ANTIQUITAS 26 (2002):

E. Lo Cascio, Considerazioni sul numero e sulle fonti di approvvigionamento degli schiavi in età imperiale 51-65; G. Marasco, La fondation et les débuts de Constantinople: éloge et psogos dans la tradition contemporaine 79-96; P. Salmon, L'infanticide et l'exposition des enfants 97-106.

14. ANTONIANUM 77 (2002) nr 1-4:

S. Kinsella - Athanasius' Life of Anthony as monastic paradigm for the First Life of St. Francis by Thomas Celano: a preliminary outline 542-556.

15. ANUARIO DE HISTORIA DE LA IGLESIA 11 (2002):

G. Fernández - Algunas cuestiones en torno a la historia antigua de la Iglesia romana 281-289. F. Vera Zorrilla - Los ,exempla” femeninos en San Ambrosio $452-457$.

16. ARCHIV FÜR GESCHICHTE DES PHILOSOPHIE 84 (2002) nr 1-3:

D.G. Robertson - A Patristic Theory of Proper Names 1-19.

17. ARCHIVIO DI FILOSOFIA 70 (2002) nr 1-3:

J.M. Soskice - Philo and Negative Theology 491-504; B. Dehandschutter - 
Théologie négative: la contribution des textes gnostiques et hermétiques 505 513; H. Vase Frandsen - Sur l'ontologie de la théologie négative. Individu et univers chez Denys l'Aréopagite 515-523; A. Knuuttila - Emotions and Negative Theology in Egyptian Fathers 525-537.

18. ATENE E ROMA 47 (2002) nr 1-3:

V. Novembri - S. Ambrogio e le lacrime di Rachele 98-109.

19. ATENEUM KAPEAŃSKIE (2002) t. 138, z. 557-559; t. 139, z. 560-562:

(Z. 558) A. Swoboda - Ideat męża w pismach Epikteta i Klemensa Aleksandryjskiego 319-332.

20. ATHENAEUM 90 (2002) nr 1-2:

C. Martínez Maza - La cristianización de Britania en dos epístolas de Gregorio Magno 507-529.

21. AUGUSTINIANA 52 (2002) nr 1-4:

(Nr 1) M. Strauss - Die Augustinusvita von Benozzo Gozzoli aus der Kirche S. Agostino in San Gimignano 1-111; M. Lamberigts - Recent research into pelagianism eith particular emphasis on the role of Julian of Aeclanum 175198; M. Verschoren - The Appearance of the concept Concupiscentia in Augustine's early antimanichean Writings (388-391), 199-240; J. Lössl Augustine on Predestination: Consequences for the Reception 241-272; J. Yates - The Epistle of James in Augustine and his Pelagian Adversaries: some Preliminary Observations 273-290.

22. AUGUSTINIANUM 42 (2002) nr 1-2:

F. Manzi - L'annullamento della maledizione di Dt. 21,23 in Galati e nel "Dialogo con Trifone» 5-34; S.A. Panimolle - La libertà dalla legge mosaica nell' «Adversus haereses» di S. Ireneo 35-74; P. Laurence - Helena, mère de Constantin. Métamorphoses d'une image 75-96; A. Di Berardino - La cristianizzazione del tempo nei secoli IV-V: la domenica 97-125; B. Studer - Zur Bedeutung der heiligen Schrift in Augustins "De Trinitate» 127-147; M. Marrocco - Participation in divine life in the "De Trinitate» of St. Augustine 149-479; B. Alexanderson - Réflexions sur l'édition récente des Psalmi graduum de S. Augustin 187-204; M. Ghilardi - Le catacombe di Roma tra la tarda antichità e l'alto medioevo 205-236; R. Romano - Opere minori di Costantino Acropolita 237-248; N. Cipriani - La presenza di Mario Vittorino nella riflessione trinitària di Agostino 261-313; F. Cori A proposito di due articoli sull'edizione critica delle "Enarrationes in Psalmos" 119-133 di Agostino 315-346; R.A.M. Bertacchini - Agostino d'Ippona fra tardoantichità e medioevo: a proposito degli indirizzi storiografici 347-382; M.B. Zorzi - „Melos" $e$,iubilus” nelle "Enarrationes in Psalmos» di Agostino: una questione di mistica agostiniana 383-413; B. Alexanderson - «Gesta collationis Carthaginiensis»: loci nonnulli cum editione Lancelii comparati 415-444; J. Vilella - Las relaciones eclesiásticas de Hispania con África en época vándala (A. 429-533) 445-468; J. Moorhead 
- The figure of the deacon Peter in the "Dialogues» of Gregory the Great 469-479; I. Pásztori-Kupán - Fragments of Theodoret's "De sancta et vivifica Trinitate» in Euthymius Zigabenus' "Panoplia dogmatica» 481-489.

23. AUGUSTINUS 47 (2002) nr 184-187:

J. Anoz - El Padre en la predicación agustiniana 5-39; F.B.A. Asiedu Pablo y la retrospectiva de Agustín sobre si mismo: relevancia de la 'epistula XXII' 41-66; R Burnell - Argumentos de Hannah Arendt y de Martin Heidegger con respecto al concepto de paraíso celestial, en san Agustín 6777; C. García López - La mirada en el 'Tesoro' de Manes 79-95; J.A. Moreno Urbaneja - Los grados del don, a partir de san Agustín 97-109; C.J.N. de Paulo - Ser y conversión. Ensayo de fenomenología agustiniana 111-154; E. Sánchez - El comentario de Ambrosio y Agustín sobre la perícopa de la adúltera $\left(J_{n} 7,53-8,11\right)$. Parte segunda: análisis comparativo 155-184; J. Anoz - Cronología de la producción agustiniana 229-312; T.C. Madrid - San Agustín hoy: dónde y cómo 313-331; M.T. Clark - El humanismo cristiano de san Agustín 333-361; P. Langa Aguilar - Al servicio de la unidad, desde la polémica donatista 363-383; J. Oldfilld: El ánimo fraterno me comprende 411-425; C.J.N. de Paulo - P.A. Messina: Hermenéutica agustiniana de la voluntad, en santo Tomás de Aquino 427-455.

24. BIBEL UND LITURGIE 75 (2002) nr 1-4:

K. Scholtissek - Das Neue Testament und die nichtkanonischen Schriften des frühen Christentums. Zu einer Sammlung und Neuübersetzung von K. Berger und Ch. Nord 287-290.

25. THE BIBLE TODAY 40 (2002) nr 1-6:

S.J. Tanzer - Jewish-Christian Relations and the Gospel of John 99-105;

O. Bucher - The Gospel for the First-Century World 159-165;

26. BIELSKO-ŻYWIECKIE STUDIA TEOLOGICZNE 3 (2002):

P. Gregor - Dyscyplina pokutna Kościoła w pierwszych trzech stuleciach 389-406; M. Rosik - Starożytne przekłady syryjskie „Modlitwy Pańskiej” (Mt 6, 5-15 [9b-13]), 495-502.

27. BIULETYN ORMIAŃSKIEGO TOWARZYSTWA KULTURALNEGO (2002) nr 28-31:

(Nr 30/31) M. Gillert - Kościót ormiański wyznacznikiem tożsamości narodowej 4-53.

28. BULLETIN DE LITTERATURE ECCLÉSIASTIQUE 103 (2002) nr 1-4:

G. Gobillot - Les "Gens du Livre», juifs et chrétiens d'Égypte: du début de la conquête arabo-islamique (640) à la fin de la dynastie fatimide (1171) (I) 6796; (II) 153-186; S.J.G. Sanchez - Le manuscrit du "Dialogue avec Tryphon" de Justin Martyr 371-382.

29. BYZANTION 72 (2002) nr 1-2:

A. Andreopoulos - The Mosaic of the Transfiguration in St. Catherine's 
Monastery on Mount Sinai: A Discussion of its Origins 9-41; T. Brauch Notes on the Prefects of Constantinople AD 366-369, 42-104; N. Delierneux - Anne-Euphémianos, l'épouse devenule eunuque: Continuité et évolution d'un modèle hagiographique 105-140; C. Foss - The Empress Theodora 141-176; M. Kulikowski - Marcellinus „of Dalmatia” and the Dissolution of the Fifth-Century Empire 177-191; I. Shahîd - The Thematization of Oriens. Final Observations 192-249; A. Borovilou - Baroccianus Gr. 50:

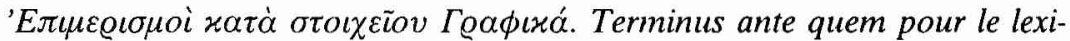
que de Théodose le Grammairien (IX ${ }^{e}$ s.) 250-269; B. Koutava-Delivoria La contribution de Constantin Porphyrogénète à la composition des "Geoponica» 365-380; J. Signes-Codoñer - Helenos y Romanos: la cultura bizantina y el islam en el siglo IX,404-448.

30. CAHIERS DU CERCLE ERNEST RENAN (2002) nr 217-220:

(Nr 217) A. Lama - Les Flaviens et le judaïme (fin) 5-43; (nr 220) P. DanePratiques magiques et superstitions de l'Église 79-100; (nr 218) P. Dane Cupiditè et corruption de l'Église (les biens ecclésiastiques) 23-40.

31. CENOBIUM (2002) nr 17:

"Reguta Mistrza» (RMProl - RM 2), thum. T.M. Dąbek 7-31; T.M. Dąbek Rozważania wokót "Reguty» św. Benedykta 33-40.

32. CERKIEWNY WIESTNIK 2002, nr 1-4:

(Nr 2) P. Chomik - Ikona w cerkwi prawosławnej 12-25; (nr 4) G. Peradze Pojęcie, zadania $i$ metody patrologii w teologii prawostawnej 13-20; A. Schmemann - Символы и символизм в православной литургии 27-36.

33. DER CHRISTLICHE OSTEN 57 (2002) nr 1-6:

S.H. Mor Ignatius Zakka I. Iwas - Das Fasten in der Syrisch-Orthodoxen Kirche, übersetzt A. Gorgis 26-40; Gemeinsame Komisssion der Griechisch-Orthodoxen Metropolie von Deutschland und der römisch-katholischen Kirche in Deutschland - Die Gemeinschaft der Heiligen als Gabe und Aufgabe 93-116; O.F.A. Meinardus - Die Apostel in der Frömmigkeit der Kopten 117-128; E.Ch. Suttner - Die orthodoxe Welt und der lateinische Westen - Gegensatz oder Ergänzung 144-154; J. Petrossian - Die Armenische Apostolische Kirche 156-200; D. Burghardt - Von liturgischen Gewändern und Kleidern als Symbolen 238-250; O.F.A. Meinardus - Patriarchen und Propheten in der koptischen Frömigkeit 251-259;

34. CHRISTUS 49 (2002) $\mathrm{nr}$ 193-196:

M. Neusch - De la crainte à l'amour chez saint Augustin 295-305.

35. CHURCH HISTORY 71 (2002) nr 1-4:

F. Beatrice - The Word „Homoousios" from Hellenism to Christianity 243272; D. Brakke - The Early Church in North America: Late Antiquity, Theory, and the History of Christianity 473-491; G.E. Minton - ,The some cause and like quarell": Eusebius, John Foxe, and the Evolution of Ecclesiastical History 715-742. 
36. CHURCHMAN 116 (2002) nr 1-4:

G. Bray - Bishops, Presbyters and Woman 7-20; M.A.G. Haykin-Bauty as a Divine Attribute: Sources and Issues 127-136;

37. CISTERCIAN STUDIES QUARTERLY 37 (2002) nr 1-4:

B. Noell - Aelred of Rievaulx's Appropriation of Augustine. A Window on Two Views of Friendship and the Monastic Life 123-144; E. Bianchi - The Holy Spirit in the Monastic Life 153-166; E. Dietz - Conversion in the «Sermons» of Isaac of Stella 229-259; D.A. Johnson - Did Saint Benedict Know of the Rule of Rabbula 273-277; A.E. Sweet - „Participating in the Passion of Christ": Benedict's View of Monastic Life 279-296; P. Deseille Acedia according to the Monastic Tradition 297-301; E. Cazabonne - Gregory Palamas (1296-1359): Monk, Theologian, and Pastor 303-333; J. Chryssaavgis - A Spirituality of Imperfection: The Way of Tears in Saint John Climacus 359-371.

38. LA CIVILTÀ CATTOLICA 153 (2002) t. 1, nr 3637-3642, t. 2, 3643-3649, t. 3, nr 3649- 3653 (quaderno):

(Nr 3639) G. De Rosa - L'Eucaristia nella vita della Chiesa. Dal I al V secolo 232-244; (nr 3643) Dal VI secolo a san Tommaso d'Aquino 41-54.

39. COLLECTANEA CISTERCIENSIA 64 (2002) nr 1-4:

D. Bertrand - Le discernement bernardin. Entre les Pères du désert et Ignace de Loyola 5-16; V. Dupont - Le disciple, chez Jean et chez Benoît 56-64; A. Böckmann - L'oratoire du monastère. Règle de saint Benoitt, chaptire 52, 105-120; D. Huerre - L'anthropologie de la Règle de saint Benoit. Une proposition pour début de siècle 173-196; J. Macho - L'abbè, symbole de la paternité de Dieu 249-261.

40. COLLECTANEA THEOLOGICA 72 (2002) nr 1-4:

(Nr 2) S. Jankowski - Judaizm poświqtynny wobec chrześcijaństwa 63-89; W. Rakocy - Problem datacji i kolokacji w misji Pawta tzw. Soboru Jerozolimskiego 31-44; W. Kluj - Pierwsze wspólnoty chrześcijańskie i ich misyjny charakter 45-62; J. Bagrowin - Inicjacyjno-katechumenalny ksztatt wychowania religijnego 85-108; (nr 3) A. Matyszewski - droga inicjacji chrześcijańskiej wedtug «Itinerarium Egeriae» 135-154; (nr 4) A. Swoboda - Rodzina w pismach Ojców Apostolskich 37-48; J. Wąsowicz - Elementy patrologii i historii starożytnego Kościoła w wybranych podręcznikach do szkót ponadpodstawowych 179-183; K. Obrycki - Św. Ambroży w pracach dyplomowych pisanych na polskich uczelniach katolickich $w$ latach 1945 2000, 183-190; P. Wróblewski - Chrześcijaństwo w pluralistycznym świecie Cesarstwa Rzymskiego II-V wieku. Sprawozdanie z sympozjum patrystycznego 190-191.

41. COMMUNIO (ESP) 35 (2002) nr 1-2:

C. Granado - Explicacion del Símbolo de la Fe (Introduccion, traduccion y notas) 265-358. 
42. COMMUNIO (USA) 29 (2002) nr 1-4:

Y. De Andia - Martyrdom and Truth: From Ignatius of Antioch to the Monks of Tibhirine 62-88; B.E. Daley - Is Patristic Exegesis Still Usable? Reflections on the Early Christian Interpretation of the Psalms 185-216; D.C. Schindler - Freedom Beyond Our Choosing: Augustine on the Will and Its Objects 618-653.

43. COMPOSTELLE (2002) nr 5 :

J.P. Mahé - De Jérusalem à Compostelle: les deux saints Jacques des Arméniens 9-18.

44. CONCILIUM (2001) nr 289-290:

(Nr 289) S. Freyne - Dieu comme expérience et mystère. La compréhension chrétienne primitive, trad. A. Divault 79-90; ( $\mathrm{nr} 290$ ) L. Sowle Cahill - La tradition chrétienne de la guerre juste. Tensions et développement, trad. A. Divault 81-90.

45. CONNAISSANCE DES PÈRES DE L'ÉGLISE (2002) nr 85-88:

(Nr 85: Actes du colloque du 8 septembre 2001 à l'Institut Catholique de Paris) C. Dagens - Connaître et aimer les Pères de l'Église 3-4; F.X. de Guibert - H.L. Roche - Historique de la Revue Connaissance des Pères de l'Église 5-8; A. Di Berardino - Uno sguardo sugli studi patristici in Italia 9-21; J. García - Bilan des études patristiques en Espagne 22-26; F. Nuvolone Bilan des études patristiques en Suisse et dans les pays germanophones 27-35; A. Fitzgerald - La patristique dans les pays anglophones depuis vingt ans 3644; C. Badilita - La patristique en Roumanie 45-49; M. Starowieyski - Bilan des études patristiques en Pologne 50-58; M.A. Vannier - Bilan des études patristiques en France et en Belgique 59-67; G. Kongs - L'apport des Pères dans la pastorale 68-73; E. Paoli-Lafaye - L'apport de la prosopographie chrétienne du Bas-Empire aux études patristiques 74-87; M. Alexandre Pour une approche culturelle de la patristique 88-118; M. Harl - L'Europe et les Pères 119-125; (nr 86: Foi et culture) J.P. Levet - „Ce qu'il a aimé”. Une culture de la foi chez. Polycarpe de Smyrne et Ignace d'Antioche 2-8; L. Brottier - La culture hellénique au service d'une meilleure compréhension des Écritures: quelques exemples empruntés à l'œuvre de Jean Chrysostome 924; B. Gain - Basile de Césarée et la culture profane 25-33; G. Madec - Le platonisme des Pères 34-53; L. Brottier - Les tableaux de Jean Chrysostome: quand le discours devient peinture 54-57; (nr 87: Quelle vision de l'homme au temps des martyrs) D. Vigne - L'homme «théophore» Anthropologie d'Ignace d'Antioche 2-11; B. Pouderon - L'anthropologie des Apologistes grecs (II siècle) 12-26; J. Fantino - L'être humain et Dieu selon Irénée 27. 38; F. Chapot - Qu'est-ce que l'homme? Variations sur un thème anthropologique chez Tertullien 39-48; J. García - L'homme chez Origène: une anthropologie pour la spiritualité 49-59; ( $\mathrm{nr} 88$ : Quelle vision de l'homme après Constantin) L. Brottier - D'Antoine à Jean Chrysostome: permanence d'une 
spiritualité 2-26; R. Winling - Aspects significatifs de l'anthropologie de Grégoire de Nysse 27-33; M.A. Vannier - La conversion, axe de l'anthropologie de S. Augustin 34-48; A. Louf - L'homme dans l'histoire du salut selon Isaac le Syrien 49-54; G. Kongs - L'apport des Pères à l'anthropologie 55-58.

46. CRISTIANESIMO NELLA STORIA 23 (2002) nr 1-2:

R. Somos - Origenian Apocatastasis Revisited 53-77;

47. CZASOPISMO PRAWNO-HISTORYCZNE 54 (2002) nr 1:

A. Stępowska - Dziedziczenie beztestamentowe krewnych kognacyjnych $w$ świetle nowel 118 i 127 Justyniana 57-81.

48. CZESTOCHOWSKIE STUDIA TEOLOGICZNE 30 (2002):

G. Jaśkiewicz - Życie zakonne w świetle «Mów» Grzegorza z Nazjanzu 8187; S. Urbański - „Przez Jezusa do Maryi” w poezji mistycznej św. Efrema 195-204.

49. DEUTSCHE VIERTELJAHRSCHRIFT FÜR LITERATURWISSENSCHAFT UND GEISTESGESCHICHTE 76 (2002) nr 1-4:

E. Horn - Die Versuchung des heiligen Serapion. Wirklichkeitsbegriff und Wahnsinn bei E.T.A. Hoffmann 214-228

50. DEUTSCHES ARCHIV FÜR ERFORSCHUNG DES MITTELALTERS 58 (2002) nr 1-2:

K. Zechiel-Eckes - Vom Armarium in York in den Düsseldorfer Tresor. Zur Rekonstruktion einer Liudger-Handschrift aus dem mittleren 8. Jahrhundert 193-203.

51. DIALOGUES D'HISTOIRE ANCIENNE 28 (2002) nr 1-2:

M. Pillon - Hydronymie et toponymie dans les régions orientales de l'Illyricum, de la conquête romaine aux invasions slaves (II s. av. J.-C. $V I I I^{e}$ s. apr. J.-C.), 41-60; M. Melusso - In tema di „servi fugitivi in ecclesia" in epoca giustinianea. Le "Bulle Sanctae Sophiae» 61-92.

52. DIDASKALIA 32 (2002) $\mathrm{nr} 1-2$ :

P.G. Alves De Sousa - O Símbolo nos Autores da Literatura Patrística Galaico-Lusitana 9-39.

53. DISSERTATIONES PAULINORUM 11 (2002):

B. Degórski - Posłuszeństwo i pokora jako najwazniejsze cnoty mnicha $w$ dziełach sw. Hieronima 5-29.

54. DIVUS THOMAS 105 (2002) nr 31-33:

(Nr 31) C.M. Bondioli - Cristo mediatore nell'«Adversus haereses» di Sant'Ireneo 203-224.

55. EARLY MEDIEVAL EUROPE 11 (2002) nr 1-3:

N. Gradowicz-Pancer - De-gendering female violence: Merovingian female honour as an "exchange of violence” 1-18; S. DeGregorio - „Nostrorum socordiam temporum" the reforming impulse of Bede's later exegesis 107122; W. Drews - Jews as pagans? Polemical definitions of identity in Visigothic Spain 189-207. 
56. ECCLESIA ORANS 19 (2002) nr 1-3:

$\mathrm{J}$. Driscoll - Uncovering the Dynamic „Lex orandi - lex credendi” in the Trinitarian Theology of Origen 63-100; G. Bonaccorso - la dinamica simbolica del sacramento 349-373.

57. THE ECUMENICAL REVIEW 54 (2002) nr 1-4:

Hegumen Hilarion (Alfeyev) - The Patristic Heritage and Modernity 91111.

58. ELPIS 4 (2002) nr 6:

P. Martyniuk - Duchowość Wschodu 13-24; D. Sawicki - Modlitwa Jezusowa i jej wpływ na rozwój duchowości 39-52; J. Tofiluk - Hezychazm i jego wplyw na rozwój duchowości 87-108; D. Popescu - Aspekty dogmatyczne liturgii prawosławnej, tłum. H. Paprocki 111-119; W. Tsingos-Człowiek $i$ jego odrodzenie według dogmatyki Kościoła prawosławnego w aspekcie bizantyjskiej tradycji liturgicznej, tłum. J. Pańkowski 120-143; J. van Rossum - Eucharystia w teologii św. Grzegorza Palamasa, thum. B. Doroszkiewicz 144-154; H. Paprocki - Dogmat Niepokalanego Poczęcia (prawosławny punkt widzenia) 253-259; H. Paprocki - Diakonisy (historia $i$ wspótczesność) 260-272.

59. ELCKIE STUDIA TEOLOGICZNE 3 (2002):

M. Sieńkowski - Elementy duchowości chrześcijańskiej w Liście do Kościoła w Koryncie św. Klemensa Rzymskiego 89-105.

60. ENCOUNTER 63 (2002) nr 1-2:

D. Bundy - Bishop Vologese and the Persian Siege in 359 C.E.: A Study in Ephrem's «Mēmrē on Nicomedia» 55-63.

61. EPHEMERIDES LITURGICAE 116 (2002) nr 1-4:

R. Fusco - Il nuovo "Martyrologium Romanum»: considerazioni da una campionatura sui primi dieci giorni di ottobre 72-95; A. Ward - The Deacons of the "Martyrologium Romanum» 96-125; R. Fusco -- Agiografia e fonti liturgiche: la nuova „Praefatio II de sanctis Martyribus” nel Messale Romano 307-319; F. Manns - Liturgia ebraica e liturgia cristiana a confronto: problemi di metodologia 404-418.

62. EPHEMERIDES THEOLOGICAE LOVANIENSES 78 (2002) nr 1-4:

(T. 1) G. Kalantzis - „Duo filii” and the „Homo Assumptus” in the Christology of Theodore of Mopsuestia: The Greek Fragments of the "Commentary on John» 57-78; (T. 2-3) Elenchus bibliographicus 2002, 1-831; (T. 4) D.J. Bingham - Hope in Irenaeus of Lyons 265-282; C. Houtman - Der „Tatian” des Pentateuch: Einheit und Kohärenz in Exodus 19-40, 381-395.

63. ERBE UND AUFTRAG 78 (2002) nr 1-6:

T. Heither - Erlösung als Geschäft oder: Lohnt es sich, Christ zu sein? 128140; Ch. Joest - Basilius der Große (330-379) und seine Familie 141-146; A. Böckmann - Von den Werkzeugen und Sachen des Klosters (Regula Benedicti, cap. 32), 263-275; M. Pesch - Sind wir arm? Sollen wir arm sein? Zur 
Frage nach unserer Armut in einer benediktinischen Gemeinschaft 276-285; M. Schambeck - Sich in Gott einwurzeln und so Welt gestalten. Zum Verständnis von Contemplatio bei Gregor dem Großen 286-300; P. Bielefeld Erlösung vom Tod. Christus als Überwinder des Todes 301-313; P. Luislampe - Kontemplation als schauende Aufmerksamkeit für Gott. Zur Bedeutung der Kontemplation bei Gregor dem Großen unter besonderer Berïcksichtigung des II. Buches der «Dialoge» 370-381; P. Bielefeld - Jesus Christus, das Bild des unsichtbaren Gottes 382-393; H. Krins - Die fünf Verheißungen an den heiligen Benedikt 394-396; M. Ellinger - „Habitare secum - Wohnen in sich selbst". Kontemplation bei Papst Gregor dem Großen im zweiten Buch seiner "Dialoge» 452-471.

64. ESPE (2002) nr 58-60:

(Nr 58) Perly z Tradycji. Szczęśliwszy, kto ubóstwem się podpiera (Minucjusz Feliks - OŻ II 370-371; Klemens Aleksandryjski - OŻ III 204-205), fragmenty wybral A. Langhammer 78-79; (nr 59) Perly z Tradycji. Zwierciadto czystości (św. Ambroży - PSP 35), fragmenty wybrał A. Langhammer 202-204; E. Kryściak - Święta męczennica (Agnieszka) 74; (nr 60) Perty z Tradycji. Ksiązka czyni dusz̨̧ wewnętrznie pięknq (św. Cezary z Arles OŻ IV 528-528), fragmenty wybrał A. Langhammer 68-69; E. Kryściak Nauczyciel Hiszpanii (św. Izydor z Sewilli) 70.

65. ESTUDIO AGUSTINIANO 37 (2002) nr 1-3:

P. De Luis - Comentario a la Regla de san Agustín. Capítulo segundo (II), 5-74; Capítulo tercero (I), 275-317; (II) 451-521.

66. ESTUDIOS BÍBLICOS 60 (2002) nr 1-4:

L.H Feldman - "The death of Moses», according to Philo 225-254; T. Löfstedt - A message for the last days: "Didache» 16, 1-8 and the New Testament Traditions 351-380.

67. ETHOS 15 (2002) nr 57-60:

(Nr 59-60) G. Reale - Trzy paradygmaty metafizyki stworzone przez myśl greckq $i$ chrześcijańskq, tłum. E.I. Zieliński 20-29.

68. LES ETUDES CLASSIQUES 70 (2002) nr 1-3:

Ch.M. Ternes - L'Europe dans l'oeuvre d'Ausone 93-99.

69. ETUDES THÉOLOGIQUES \& RELIGIEUSES 77 (2002) nr 1-4:

M. Despland - L'évêque, le lièvre et le chien 401-414.

70. EUROPEAN JOURNAL OF THEOLOGY 11 (2002) nr 1-2:

R. Riesner - Der Hebräer-Brief nach Altkirchlichen Zeugnissen 15-29.

71. FAITH AND PHILOSOPHY 19 (2002) nr 1-2:

K.A. Rogers - The Abolition of Sin: A Response to Adams in the Augustinian Tradition 69-84.

72. FRANCIA 29 (2002) nr 1:

R. Kaiser - Autonomie, Integration, bilateraler Vertrag - Rätien und das Frankreich im frïhen Mittelalter 1-27. 
73. FORUM KATHOLISCHE THEOLOGIE 18 (2002) nr 1-4:

J.J. Ayán Calvo - Datierung und Echtheit der Ignatianischen Briefe 81-105.

74. GREGORIANUM 83 (2002) nr 1-4:

N.T. Wright - Jesus' Resurrection and Christian Origins 615-635.

75. GYMNASIUM 109 (2002) nr 1-6:

Th. Baier - Cicero und Augustinus. Die Begründung ihres Staatsdenkens im jeweiligen Gottesbild 123-140.

76. HAGIOGRAPHICA 8 (2001):

M. Jost - Die Patrozinien der Kirchen Roms während des ersten Jahrtausends. Entstehung, Bedingungen und Zusammensetzung 1-34; S. GavinelliPer una edizione della "Vita Sancti Gaudentii»: i codici carolingi 35-86; W.D. McCready - Miracles at Eleventh-Century Montecassino: Gregory the Great and the Desiderian "Dialogues»87-119; E. D'Angelo - Il dossier delle sante Flora e Lucilla e la "Augmentatio passionis» (BHL 5021c), 121-164.

77. HARVARD THEOLOGICAL REVIEW 95 (2002) nr 1-4:

S. Emmel - The Recently Published "Gospel of the Savior» (,Unbekanntes Berliner Evangelium"): Righting the Order of Pages and Events 45-72; J. Joosten - The "Gospel of Barnabas» and the "Diatessaron" 73-96; C.W. Griffin - D.L. Paulsen - Augustine and the Corporeality of God 97118; J.Z. Pastis - Dating the "Dialogue of Timothy and Aquila»: Revisiting the Earlier „Vorlage” Hypothesis 169-195; S.J.D. Cohen - Judaism without Circumcision and "Judaism" without "Circumcision” in Ignatius 395-415;

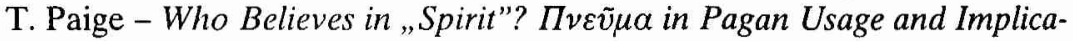
tions for the Gentile Christian Mission 417-436.

78. HEILIGER DIENST 56 (2002) nr 1-4:

M. Puzicha - „Es geschehe mit Demut, Ernst und Ehfurcht” (RB 47, 3). Der

Dienst des „Lektors” in der Benediktusregel 266-276.

79. HERMENEIA (2002) nr 1-2:

(Nr 1) A. Kallis - Tod und Auferstehung in der Orthodoxen Kirche und Theologie. Vom Fest der christlichen Identität 7-25; (nr 2) J. Zerlin - Im Spiegel der Lampen. Von den Anfängen christlicher Symbolik und Ikonographie an spätantiken Öllampen (Teil 5), 41-50.

80. HERMES 130 (2002) nr 1-4:

A. Coşkun - Trennungsschmerz eines anhänglichen Vaters. Zum Hintergrund von Ausonius, "Pater ad filium» 209-222; V. Buchheit - Laktanz und seine "testimonia veritatis" 306-315; Ch. Tornau - Augustinus und das "hidden curriculum": Bemerkungen zum Verhältnis des Kirchenvaters zum Bildungwesen seiner Zeit 316-337; H. Tränkle - Vermeintliche Interpolationen bei Paulinus von Nola 338-361; Ch. Gnilka - Textprobleme bei Paulinus Nolanus 362-377.

81. THE HEYTROP JOURNAL 43 (2002) nr 1-4:

P.F. Bradshaw - Did the Early Eucharist ever have a Sevenfold Shape? 73- 
75; F.B.A. Asiedu - Augustine's Christian-Platonist Account of Goodness: A Reconsideration 328-343; A. Meredith - Origen and Gregory of Nyssa on the Lord's Prayer 344-356.

82. HISPANIA 62 (2002) nr 210-212:

A. Isla Frez - El „officium palatinum” visigodo. Entorno regio y poder aristocrático 823-848.

83. HISTORIA 51 (2002) nr 1-4:

G. Wesch-Klein - Der Laterculus des Polemius Silvius - Überlegungen zu Datierung, Zuverlässigkeit und historischem Aussagewert einer spätantiken Quelle 57-88; M. Meier - Kaiserherrschaft und "Volksfrömmigkeit" im Konstantinopel des 6. Jahrhunderts n. Chr. Die Verlegung der Hypapante durch Justinian im Jahr 542, 89-111; W. Riess - Die historische Entwicklung der römischen Folter- und Hinrichtungspraxis in kulturvergleichender Perspektive 206-226; T.D. Barnes - Valentinian, Auxentius and Ambrose 227-237; Ph. Bruggisser - Rarissimes païens. L'art du persiflage dans le "Contre Symmaque» de Prudence 238-253; E. Wirbelauer Aberkios, der Schüler des reinen Hirten, im Römischen Reich des 2. Jahrhunderts 359-382; H. Dolenz - R. Jernej - Zum Umbau des Amphitheaters von Virunum in den Jahren 183/184 n. Chr. Archäologische und epigraphische Quellen in Ergänzung 481-501; M. Lolli - „Massenziobis” in "Pan.»IV $(X)$ [321 d. C.]: il monito di Costantino imperatore al collega Licinio 502-508.

84. HISTORISCHE ZEITSCHRIFT 274 (2002) nr 1-3:

J. Spielvogel - Die historischen Hintergründe der gescheiterten Akkulturation im italischen Ostgotenreich (493-553 n. Chr.) 1-24;

85. IRÉNIKON 75 (2002) nr 1-4:

A. Peckstadt - L'autorité dans l'glise: une approche orthodoxe 35-52; B. Mailleux - Hérité par l'Esprit: une approche de la théologie du salut chez saint Irénée 147-173.

86. IRISH BIBLICAL STUDIES 24 (2002) nr 1-4:

M. Dowling - Proverbs 8, 22-31 in the Christology of the Early Fathers 99 . 117; C.A. Smith - The Consequences of the Increase in and the Changed Role of Letter-Writing for the Early Church 146-174.

87. IRISH THEOLOGICAL QUARTERLY 67 (2002) nr 1-4:

D. Woods - Eusebius on Some Constantinian Officials 195-223; I. Davidson - Reappropriating Patristic Christology: One Doctrine, Two Styles 225239.

88. ISTINA 47 (2002) nr 1-4:

J. de Pergame - L'institution synodale. Problèmes historiques, ecclésiologiques et canoniques 14-44; Saint Grégoire l'Illuminateur et la conversion de l'Arménie à la foi chrétienne (Erevan et Etchmiadzine, 23-27 septembre 2001) - documents 309-314. 
89. JAHRBUCH FÜR LITURGIK UND HYMNOLOGIE 41 (2002):

J. Conrad - Die altspanische Liturgie in Toledo als Ausdrucksform mittelalterlichen Landeskirchentums 54-67.

90. THE JEWISH QUARTERLY REVIEW 92 (2001) nr 1-4:

L.H. Feldman - The Portayal of Phinehas by Philo, Pseudo-Philo, and Joesphus 315-345.

91. JOURNAL OF BIBLICAL LITERATURE 121 (2002) $\mathrm{nr}$ 1-4:

P.B. Munoa III - Jesus, the „Merkavah”, and Martyrdom in Early Christian Tradition 303-325.

92. JOURNAL OF COPTIC STUDIES 4 (2002):

$\mathrm{R}$. Cortopassi - Les toiles en lin à décor broché dans la collection de tissus égyptiens du musée du Louvre 1-24; Ch. Joest - Die Pachom-Briefe 1 und 2. Auflösung der Geheimbuchstaben und Entdeckungen zu den Briefüberschriften 25-98; O.F.A. Meinardus - Stätten der Gotteserfahrung in koptischen Traditionen: Bäume, Höhlen und Quellen 99-112; H. Förster - Vier Wiener koptische Papyrusfragmente 113-126; Ch.W. Hedrick - Newly Identified Fragments of Coptic Acts and the Apocalypse 127-132; K. SchüsslerAnalyse der Lektionarhandschrift sa 530, $133-165$; H. Suermann - Koptische Texte zur arabischen Eroberung Ägyptens und der Umayyadenherrschaft 167-186; Y.N. Youssef - Recomendations to the Priests Severus of Antioch or Severus of El-Ashmunein 187-196.

93. JOURNAL OF EARLY CHRISTIAN STUDIES 10 (2002) nr 1-4:

S.J. Davis - Crossed Texts, Crossed Sex: Intertextuality and Gender in Early Christian Legends of Holy Women Disguised as Men 1-36; F.G. McLeod The Christological Ramifications of Theodore of Mopsuestia's Understanding of Baptism and the Eucharist 37-75; W.E. Klingshirn - Defining the Sortes Sanctorum: Gibbon, Du Cange, and Early Christian Lot Divination 77-130; M. Penn - Performing Family: Ritual Kissing and the Construction of Early Christian Kinship 151-174; C. Conybeare - The Ambiguous Laughter of Saint Laurence 175-202; J. Lössl - Julian of Aeclanum on Pain 203-243; R. Cross - Individual Natures in the Christology of Leontius of Byzantium 245-265; N. Constas - An Apology for the Cult of Saints in Late Antiquity: Eustratius Presbyter of Constantinople, "On the State of Souls after Death" (CPG 7522) 267-285; C. Osiek - Perpetua's Husband 287-290; A. H. Becker - Anti-Judaism and Care for the Poor in Aphrahat's "Demonstration» 20, 305-327; M. Malamud - Writing Original Sin 329-360; M. L. Colish - Why the Portiana? Reflections on the Milanese Basilica Crisis of 386, 361-372; J. T. Lienhard - 2001 NAPS Presidential Address: The Christian Reception of the Pentateuch: Patristic Commentaries on the Books of Moses 373-388; D. Kimber Buell - Race and Universalism in Early Christianity 429-468; B.E. Daley - „Heavenly Man” and „Eternal Christ”: Apollinarius and Gregory of Nyssa on the Personal Identity of the Savior 469-488; 
R.A. Layton - Plagiarism and Lay Patronage of Ascetic Scholarship: Jerome, Ambrose, and Rufinus 489-522.

94. THE JOURNAL OF ECCLESIASTICAL HISTORY 53 (2002) nr 1-4: W. Treadgold - Photius beforc his Patriarchate 1-17; A. Brent - Cyprian's Reconstruction of the Martyr Tradition 241-268; D. Hipshon - Gregory the Great's „Political Thought” 439-453.

95. JOURNAL OF THE HISTORY OF PHILOSOPHY 39 (2001) nr 1-4: M. Mendelson - By the Things Themselves: Eudaimonism, Direct Acquaintance and Illumination in Augustine's "De magistro» 467-489.

96. JOURNAL FOR THE STUDY OF THE PSEUDOEPIGRAPHIA 12 (2002) nr 1-2:

J.E. Taylor - Virgin Mothers: Philo on the Women Therapeutae 37-63; A.Y. Kim - Cain and Abel in the Light of Envy: A Study in the History of the Interpretation of Envy in Genesis 4, 1-16, 65-84; D.C. Allison - Job in the "Testament of Abraham» 131-147; M.F. Whitters - Testament and Canon in the "Letter of Second Baruch" (2 Baruch 78-87), 149-163.

97. THE JOURNAL OF THEOLOGICAL STUDIES 53 (2002) nr 1-2:

K.L. Gaca-Driving Aphrodite from the World: Tatian's Encratite Principles of Sexual Renunciation 28-52; Ph.R. Amidon - Paulinus' Subscription to the "Tomus ad Antiochenos» 53-74; I. Pásztori-Kúpan - An Unnoticed Title in

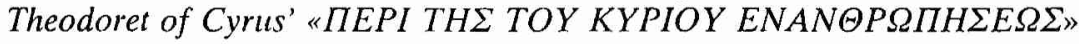
102-111; W.S. Watt - The Text of Ambrose's "De Officiis» 112-118; J.C. O'Neill - How early is the Doctrine of "Creatio ex nihilo"? 449-465; E. Digeser - Porphyry, Julian, or Hierocles? The Anonymus Hellene in Makarios Magnes' Apokritikos 466-502; A. Whealey - The Apocryphal Apocalypse of John. A Byzantine Apocalypse from the Early Islamic Period 533-540; P.L. Buck - The Pagan Husband in Justin, "2 Apology» 2, 1-20, 541-546; D. Wood - Gregory Thaumaturgus and the Earthquake of 344, 547 553; A. Breeze - Elaphus the Briton, St Germanus, and Bede 554-557.

98. KALISKIE STUDIA TEOLOGICZNE 1 (2002):

M. Kieling - Wktad Alkuina w odnowe teologicznq epoki karolińskiej 161173; I. Pająk - Ojcostwo św. Józefa w świetle literatury patrystycznej 361-367. 99. KERYKS 1 (2002):

S. Bielecki - Chrześcijański kéryks 37-51; A. Eckmann - Osobowość dobrego katechety w świetle "De catechizandis rudibus» św. Augustyna 53-60.

100. KIRCHE UND ISRAEL 16 (2001) nr 1-2:

D. Boyarin - Als Christen noch Juden waren. Überlegungen zu den jüdisch-christlichen Ursprïngen, übersetzt W. Stegemann 112-129.

101. КИРИЛО-МЕТОДИЕВСКИ СТУДИИ 14 (2001):

И. Тот - Библейские цитатьы в «Вердальном поведени» Константина Философа 40-44; W. Stępniak - Sw. Katarzyna Aleksandryjska u Stowian Południowych i Zachodnich 197-204. 
102. LAÓS 9 (2002) nr 1-2:

(Nr 1) A. de Maria - La Chiesa nella teologia africana tra III e IV secolo (II), 34-44; (nr 2) A. de Maria - Cristianesimo e Islam: Storia di un confronto 65-76.

103. LEGNICKIE WIADOMOŚCI DIECEZJALNE 11 (2002) nr 1-4:

R. Kisiel - Patrystyczne źródła chrześcijańskiej antropologii filozoficznej 86-91.

104. LITERATŪRA 43 (2001) nr 3:

D. Alekna - $\breve{S}$ v. Augustinas ir retorika: paradoksali gynyba 97-105.

105. LITURGIA SACRA 8 (2002) nr 1-2:

M. Pisarzak - Nazwy liturgii na Zachodzie 43-57.

106. MAGISTRA 8 (2002) nr 1-2:

(Nr 1) M.B. Smyth - Widows, Consecrated Virgins and Deaconesses in Ancient Gaul 53-84; (nr 2) B. McNary-Zak - Problematizing women and Holy Land Pilgrimage in Late Antiquity 3-24; A. Minore - Julian of Norwich and Saint Benedict 45-61; J.N. Brown - The Rule of St. Benedict and Envisioning Jesus 62-76.

107. LA MAISON DIEU (2002) nr 229-232:

(Nr 231) M.L. Chaieb-Bourgueil - Temps et sacramentalité dans la théologie eucharistique d'Irénée de Lyon 67-90; (nr 232) M. Corbin - „Il nous a donné sa mort en gage". Le mystère pascal chez saint Augustin 35-74.

108. MARIANUM 63 (2001) nr 159-160:

M. Van Esbroeck - Some earlier features in the "Life of the Virgin» 297-308.

109. MEANDER 57 (2002) nr 1-4:

M. Eder - Traktat Nowacjana «O widowiskach» - kilka uwag o tekście $i$ autorze 59-68; Nowacjan - «O widowiskach», thum. $\mathrm{zb}$. pod kierunkiem J. Pigonia 69-75; A. Kwaczek - «De spectaculis» Nowacjana - kompozycja, wzorce, odniesienia 77-85; M.J. Leszka - Aelia Zenonis, żona Bazyliskosa 87-93; A.M. Komornicka - Rady Grzegorza z Nazjanzu dla kaznodziejów 171-173; K. Narecki - Historia powstania stownika H.G. Liddella: A Greek-English Lexicon 205-223.

110. MÉLANGES DE L'ÉCOLE FRANÇAISE DE ROME 113 (2001) nr 1 (Moyen Âge):

D. Rovina - Insediamenti rurali tra antichità e medioevo; il sito di Santa Filitica 9-26.

111. MELITA THEOLOGICA 53 (2002) nr 1-2:

J. Lupi - Saint Augustine's Doctrine on Grace (I) 41-64; (II) 175-184.

112. MEMORANDA 76 (2002) nr 1-4:

M. Dylewska - Koncepcja świętych wizerunków u św. Jana Damasceńskiego 672-678.

113. MIEJSCA ŚWIĘTE (2002) nr 1-12:

(Nr 1) J.S. Partyka - Kartagina - dziedzictwo Dydony 6-9; J.S. Partyka - 
Afryka prowincja Rzymu 10-16; J.S. Partyka - Otwarty brzuch Melkarta 16-18; J.S. Partyka - Zanim urodzit się Augustyn. Początki chrześcijaństwa w Afryce Rzymskiej 19-21; J. Naumowicz - Jak stawać się chrześcijaninem. Aforyzmy Tertuliana 22-23; (nr 2) J. Kręcidło - Sq Anglami, niech będq aniotami 4-5; J. Strzelczyk - Wyspa świętych i uczonych 6-9; R. Bulas Bóg i człowiek - wspóttwórcy świata. Kościót celtycki w Irlandii 12-17; J. Naumowicz - Święty Patryk - Apostot Zielonej Wyspy 18-21; A. Datko - Krzyż i jarzębina wiedzy 22-24; J. Miazek - Liturgia celtycka 25-26; M. Wojciechowski - Ruiny, świątynie i pejzaże 27-28; E. Dożańska Homilie $w$ kamienilu 29-32; Z. Sareło - Śladami św. Kolumby 49-52; (nr 4) J. Strzelczyk - Pielgrzymowanie do Jerozolimy 4-7; J.S. Partyka Najstarsze wizerunki Jezusa Chrystusa 12-15; J.S. Partyka - Acheropity bizantyjskie 16-19; (nr 8) J.S. Partyka - Syn tylu tez 8-16; J.S. Partyka Poczq̨ek końca rzymskiej Afryki 17-18; I. Jurek - Umiłowanie mądrości 19; Z. Kubiak - Pożegnanie w Ostii 20-21; J.S. Partyka - Ostia. Ujście Tybru 22-27; J. Naumowicz - Doktor taski 31-32; J.S. Partyka - Arianizm. Religia Wandalów 33-35; J. Strzelczyk - Czarna legenda Wandalów 36-38; (nr 12) C. Napiórkowski - Ikonoklazm, czyli spór o obrazy 22-25; A. Jacyniak - Mistyka Wschodu 31-34; J. Kazimierczak - Maryja obrazem Kościoła 40-42; J.S. Partyka - Najstarsze wizerunki Matki Bożej w katakumbach 43-45.

114. MNEMOSYNE 55 (2002) nr 1-6:

S. Bobzien - A Greek Parallel to Boethius' "De hypotheticis syllogismis" 285-300; A. Coşkun - Chronology in the "Eucharisticos» of Paulinus Pellaeus: A Reassessment 329-344.

115. MODERN BELIEVING 43 (2002) nr 1-4:

(Nr 3) W.H.C. Frend - The MCU and the Study of the Early Church 39-42; (nr 4) I. Moody - Catching Chrysostom: An Ancient Ministry for a Modern World 18-24.

116. THE MODERN SCHOOLMAN 79 (2002) nr 1-4:

J.R. Fortin - , Satisfactio" in St. Benedict's "Regula» and St. Anselm "Cur Deus Homo" 305-311.

117. MODERN THEOLOGY 18 (2002) nr 1-4:

S. Coakley - Re-thinking Gregory of Nyssa: Introduction Gender, Trinitarian Analogies, and the Pedagogy of "The Song» 431-443; L. Ayres - On Not Three People: The Fundamental Themes of Gregory of Nyssa's Trinitarian Theology as Seen in «To Ablabius: On Not Three Gods» 445-474; M.R. Barnes - Divine Unity and the Divided Self: Gregory of Nyssa's Trinitarian Theology in its Psychological Context 475-496; B.E. Daley Divine Transcendences and Human Transformation: Gregory of Nyssa's Anti-Apollinarian Christology 497-506; M. Laird - Under Solomon's Tutelage: The Education of Desire in the "Homilies on the Song of Songs» 
507-525; L. Turcescu - „Person” versus „Individual”, and Other Modern Misreadings of Gregory of Nyssa 527-539; D.B. Hart - The Mirror of the Infinite: Gregory of Nyssa on the „Vestigia Trinitatis” 541-561.

118. MONASTICA 43 (2002) nr 1-3:

D. Huerre - S. Benedetto parla ancora (nr 1) 43-44; (nr 2) 33-35; (nr 3) 3941.

119. MORALIA 25 (2002) nr 1-4:

M. Raczkiewicz - Evagrio Póntico. De ocho espíritus de malicia 219-253. 120. MÓWIĄ WIEKI (2002) nr 1-12:

(Nr 1) P. Janiszewski - Aniołowie późnego antyku 6-11; (nr 4) M.B. Leszka - Helena, matka Konstantyna Wielkiego 30-32; (nr 6) P. Janiszewski-Czciciele osła 6-10); (nr 7) M.J. Leszka-Śladami Bizantyńczyków po Tesalonice 51-57; (nr 8) P. Marciniak - Bizantyńskie konkursy piękności 68; (nr 9) M.J. Leszka - Synobójczyni i święta 42-46; (nr 10) K. Janic Nestorianie w Chinach 8-11; (nr 11) Ch. Wickham - Elity wczesnego średniowiecza 6-11; M.B. Leszka - Dziewica na bizantyńskim tronie 31-35.

121. MÜNCHENER THEOLOGISCHE ZEITSCHRIFT 53 (2002) nr 1-4:

M. Thurner - Der Dialog von Angesicht zu Angesicht als Denkform. Überlegungen zur Begründung einer „Christlichen Philosophie” 308-324.

122. MUSEUM HELVETICUM 59 (2002) nr 1-4:

H. Bietenhard - Zur Etymologie des griechischen Wortes גaós/Volk 1-11; B. Bleckmann - Die Alamannen im 3. Jahrhundert: Althistorische Bemerkungen zur Ersterwähnung und zur Ethnogenese 145-171; S. Ratti-Résponses de l' «Histoire Auguste» aux apologistes Tertullien et Lactance 229-237.

123. NEDERLANDS ARCHIEF VOOR KERKGESCHIEDENIS 82 (2002) nr 1-3:

J. Stevenson - Brothers and Sisters: Women and Monastic Life in EightCentury England and Frankia 1-34; (nr 3) Index to volumes 23-80 (19302000).

124. NEDERLANDS THEOLOGISCH TIJDSCHRIFT 56 (2002) nr 1-4:

B. Wagemakers - De vlucht naar Pella. Een oude discussie en een nieuwe suggestie 89-98; P.W. van der Horst - Joden en hooligans in de late oudheid 273-279.

125. NEW TESTAMENT STUDIES 48 (2002) nr 1-4:

J. Lieu - „Impregnable Ramparts and Walls of Iron": Boundary and Identity in Early „Judaism” and „Christianity” 297-313; J.R. Edwards The "Gospel of the Ebionites» and the Gospel of Luke 568-586.

126. NICOLAUS 29 (2002) nr 1-2:

(Nr 1) R. Scognamiglio - I Padri della Chiesa e scrittori ecclesiastici in Occidente di fronte al "fare teologia" 35-51; (nr 2) M.G. Mara - La santità vocazione universale. Agostino: Le "Confessioni» 63-79; R. Scognamiglio - „Sia santificato il tuo nome” Santità del Padre e santità dei figli nella 
interpretazione dei Padri Greci alla prima petizione del Padrenostro 81-90; D. Popescu - La canonizzatione dei santi nella Chiesa ortodossa 111-125; I. Eustatios - A la recherche de la sainteté oubliée au début du nouveau millénaire. Un point de vue orthodoxe 127-136; V. Zelinsky - „Il pensiero di Cristo": la conoscenza mistica nelle "Centurie gnostiche» di San Massimo il Confessore 205-213.

127. NOUVEAUX CAHIERS MARIALS (2002) nr 65-68:

(Nr 68) B. Meunier - La sainteté de Marie. L'enseignement des Pères de l'Église 3-7.

128. NOVUM TESTAMENTUM 44 (2002) nr 1-4:

D.M. Scholer - Bibliographia Gnostica: Supplementum II/5, 55-94. S.R. Johnson - The Hidden/Revealed Saying in the Greek and Coptic Versions of "Gos. Thom." 5 \& 6, 176-185; M. De Jonge - The Two Great Commandements in the "Testaments of the Twelve Patriarchs» 371-392.

129. NOWY FILOMATA 6 (2002) nr 1-4:

B. Pawłowska - Sancti tituli w katakumbach rzymskich 57-62; R. Nakonieczny - Mowa, wymowa i rozmowa $w$ «De officiis» Cycerona $i$ «De officiis ministrorum» św. Ambrożego 109-118; S. Miozga - Symbolika Babilonu w "De civitate Dei» św. Augustyna 131-144.

130. NUMEN 49 (2002) nr 1-4:

A.A. Nagy - „Superstitio” et ,. Coniuratio” 178-192; S. Evans - The Scent of a Martyr 193-211.

131. NUOVA UMANITÀ 24 (2002) nr 139-144:

B. Bentas - Il „ritmo" trinitario della verità in Ireneo di Lione 181-195;

C. Bonfante - I Padri Cappadoci e la Trinità. Piste per una rilettura 197218; P. Coda - Il "De Trinitate» di Agostino e la sua promessa 219-248.

132. OBNOVLJENI ŽIVOT 57 (2002) nr 1-4:

A.S. Burnside - Sveti Augustin o nastanku ljudskog života 197-205.

133. ONE IN CHRIST 37 (2002) nr 1-4:

G. Tavard - Religious Philosophy and the Conversion of St Augustine 4156; J. Pelikan - Comprehensiveness or Catholicity? 12-24.

134. ORDENS NACHRICHTEN 41 (2002) nr 1-6:

(Nr 5) H. Altmann - „Jedem wurde soviel zugeteilt, wie er nötig hatte” (Apg 4, 35). Mit dem hl. Benedikt auf der Suche nach dem zum Leben Notwendigen 40-42; (nr 6) B. Hubl - Lebensqualität nach der Regel des hl. Benedikt 21-33.

135. ORIENTALIA CHRISTIANA ANALECTA (2002) t. 266-267:

(T. 266) Mgr Petit, assopmtionniste, fondateur des „Échos d'Orient”, archieveque latin d'Athenes (1868-1927). Actes du Colloque - Rome, 15-17 décembre 1997, ed. B. Holzer, Roma 2002, ss. 229; (T. 267) G. Winkler Das Sanctus. Uber den Ursprung und die Anfänge des Sanctus und sein Fortwirken, Roma 2002, ss. 281. 
136. ORIENTALIA CHRISTIANA PERIODICA 68 (2002) nr 1-2:

S. Jammo - The Anaphora of the Apostles Addai and Mari: A Study of Structure and Historical Background 5-35; V. Ruggieri-A. Acconci-J.M. Featherstone - Amboni carî e la "Vita Xenae seu Eusebiae» di Mylasa 3788; M. van Esbroeck - Traité acéphale arménien sur les trois premiers Conciles et son attribution probable à Jean Mayravanetsi 89-174; I. Zužek - Studio storico-giuridico sui titoli del patriarca dei Greco-Melkiti 175-203; A. Panayotov - The Synagogue in the Copper Market of Constantinople: A Note on the Christian Attitudes toward Jews in the Fifth Century 319-334.

137. ORTHODOXES FORUM 16 (2002) nr 1-2:

F. Gahbauer - Gottesschau und Lichtvision bei den byzantinischen Mystikern 5-17.

138. OSTKIRCHLICHE STUDIEN 51 (2002) nr 1-4:

G. Kapriev - Gibt es eine byzantinische Philosophie? 3-28; D. Schon - Zur Wahrnehmung des Islam in Ostkirchen des 9. und 10. Jahrhunderts 29-51; E. Suttner - Unwissenheit über die Anderen als Hauptursache für das Fortbestehen der Schismen zwischen Ost und West 209-224; P. ViscusoDeath in Late Byzantine Canon Law 225-248.

139. PAMIETTNIK LITERACKI 93 (2002) z. 3 :

J. Sawicka - Symbolika lunarna w średniowiecznej poezji liturgicznej 5-35.

140. PASTORES (2002) nr 14-17:

(Nr 16) J. Naumowicz - Chrystus - prawdziwy pedagog 7-12.

141. PERSPECTIVA 1 (2001) nr 1:

P. Liszka - Processiones en el Dios segun la Tradición griega y la Tradición latina 155-174.

142. PHILOLOGUS 146 (2002) nr 1-2:

A. Coşkun - Die sogenannten „Fasti” und der "Consularis liber" des Ausonius. Mit einem Exkurs zur Karriere des Proculus Gregorius 350-359.

143. PHILOSOPHIA REFORMATA 67 (2002) nr 1-2:

A.P. Bos - Gnostische spiritualität: de Grieks-filosofische component 108127; W. Elgersma Helleman - Justin Martyr and the „Logos”: an apologetical strategy 128-147.

144. PHILOSOPHICAL INVESTIGATIONS 25 (2002) nr 1-4:

C. Thompson - Wittgenstein, Augustine and the Fantasy of Ascent 153-171.

145. PHILOSOPHISCHES JAHRBUCH 109 (2002) nr 1-2:

J. Brachtendorf - Selbsterkenntnis: Thomas von Aquin als Kritiker Augustins? 254-270.

146. PHOENIX 56 (2002) nr 1-2:

A. Kalinowski - The Vedii Antonini: Aspects of Patronage and Benefaction in Second-Century Ephesos 109-149.

147. POLONIA SACRA 6 (2002) nr 10-11:

(Nr 10) S. Kaczmarek - Eklezjalny wymiar pokuty w «Listach» św. Bazy- 
lego Wielkiego 195-216; (nr 11) P. Zarębski - Macierzyński wymiar Kościoła w «Wielkiej Katechezie» św. Grzegorza z Nyssy 341-348.

148. POSITIONS LUTHÉRIENNES 50 (2002) nr 1-4:

A. Noblesse-Rocher - „L'antijudaïsme au Moyen Âge: un état de la quéstion" 121-137.

149. POZNAŃSKIE STUDIA TEOLOGICZNE (2002) nr 12-13:

(Nr 13) A. Swoboda - Rodzina w pismach Ojców Apostolskich 41-52; P. Wygralak - Hiszpańska historiografia kościelna „Anuario de Historia de la Iglesia" (1992-2001), 135-151.

150. PROCHE ORIENT CHRÉTIEN 51 (2001) nr 1-4:

G. Gianazza - Dieu Père dans la théologie arabe chrétienne 12-34; L. Perrone - Les commentaires d'Origène sur „Jean" et "Matthieu” tradition, innovation et systéme 35-69; J. Buhagiar-Bianco - La tradition des Pères l'Église: héritage ou promesse? 112-120, Isaac le Syrien - La grâce, non pas les oeuvres, présentation et trad. A. Louf 243-246; Y. de Andia Liturgie des pauvres et théologie du Corps du Christ chez saint Jean Chrysostome 247-260; Y.N. Youssef - Arabic Manuscripts of the Philalethres of Severus of Antioch 261-266

151. PRZEGLĄD NAUK HISTORYCZNYCH 1 (2002) nr 1-2:

(Nr 1) S. Bralewski - Uwagi na temat antyheretyckiego ustawodawstwa cesarza Konstantyna Wielkiego 7-20; M.J. Leszka - Konstantyna, żona cesarza Maurycjusza 21-32; (nr 2) T. Wolińska - Armeńscy wspótpracownicy Justyniana Wielkiego, cz. 1: Dezerterzy z armii perskiej w Bizancjum 5-31.

152. PRZEGLĄD POWSZECHNY 119 (2002) nr 1-12:

(Nr 1) Modlitwa św. Jana Chrzciciela, thum. R. Zarzeczny 10-11; T. Grodecki - Chrześcijańskie koncepcje filozofowania w starożytności (I): $\mathrm{nr} 1$, 90-99; (II): nr 2, 215-224; (III): nr 3, 377-386; (nr 2) Anonim - Litania do bóstwa Jezusa Chrystusa, thum. R. Zarzeczny 149-150; (nr 3) „Homilia paschalna” Jana z Berytu, tłum. R. Zarzeczny 287-288; (nr 4) „Żywot Adama i Ewy" wedtug synaksariów etiopskich 9-13, thum. R. Zarzeczny 9-13; (nr 5) Etiopski hymn przed wizerunkiem Maryi, thum. R. Zarzeczny 153-154; (nr 6) Modlitwa niedzielna z IV wieku, thum. R. Zarzeczny 305306; (nr 7-8) Hymn koptyjski o ukrzyżowaniu Pańskim, tłum. R. Zarzeczny 11-12; (nr 9) Hymn św. Pawła z «Męczeństwa św. Pelagii z Cezarei» zwanego też "Listem św. Pelagii», thum. R. Zarzeczny 193-194; (nr 10) Oda Salomona (XI), tłum. R. Zarzeczny 9-10; (nr 11) Liturgia koptyjska. Dwudziestu Czterech Starców Apokalipsy, tłum. R. Zarzeczny 141-142; (nr 12) Eloge de l'Egypte, lieu de refuge de la Parole Incarnée 287-288.

153. PRZEGLĄD RELIGIOZNAWCZY (2002) nr 203-206:

(Nr 205) W. Gajewski - Obecny stan badań nad organizacja wczesnego Kościoła w świetle pracy „Chrześcijaństwo antyczne” Tadeusza Zielińskie- 
go 39-50; (nr 206) Z.I. Brzostowski - Józef Flawiusz „strażnikiem prawa i sprawiedliwości" 3-8.

154. QUADERNI DI STORIA 28 (2002) nr 55-56:

(Nr 56) O. Longo - L'embrione è un essere vivente 119-130; R. Otranto„Le parole dei libri". Isidoro, "Etym.» VI 13 e Virgilio "Ecl.»X 67, 191. 197.

155. QUAESTIONES SELECTAE 9 (2002) nr 14-15:

(Nr 14) H. Langkammer - Niewolnictwo a pierwotny Kościół 57-71; C.M. Paczkowski - Chrzest w imį Mojżesza, Jana i Jezusa Chrystusa. Typologia chrzcielna wedlug Bazylego Wielkiego 83-106; M.B. Arndt - Lampki oliwne typu Jerash z Góry Nebo 15-21.

156. RASSEGNA DI TEOLOGIA 43 (2002) nr 1-6:

A. Carfora - Teologia eucaristica del martirio e mediazione ecclesiale in Cipriano 379-391.

157. RECHERCHES DE SCIENCE RELIGIEUSE 90 (2002) nr 1-4:

L. Padovese - L'antipaulinisme chrétien au II $I^{e}$ siècle 399-422

158. RELIGION 32 (2002) nr 1-4:

G.D. Alles - , The Most Beautiful Jewesses in the Land": Imperial Travel in the Early Christian Holy Land 205-225; R. Maisano - Filologia neotestamentaria e filologia bizantina 892-909.

159. RELIGIÓN Y CULTURA nr 220-223:

S. Sierra Rubio - Una propuesta de vida: la religión y la fe en Dios según San Agustín 687-711.

160. RES HISTORICA 13-14 (2002):

A. Krawczyk - Rola ksiązki we «Wskazaniach dotyczqcych czytania (dziet) Boskich» Flawiusza Aureliusza Kasjodora 39-85; K. Ginter - Spór o Trisagion 221-231.

161. REVISTA AGUSTINIANA 43 (200) nr 130-132:

R.M. García - Muerte y temporalidad en San Agustín. El aporte de Plotino a su idea del tiempo 5-22; J. Granados García - Vides Trinitatem si caritatem vides. Vía del amor y Espíritu Santo en el "De Trinitate» de San Agustín 23-61; G. Pons Pons - La naturaleza y el cultivo de la tierra en los comentarios de San Agustín al libro del Génesis 283-307.

162. REVISTA ESPAÑOLA DE TEOLOGÍA 72 (2002) nr 1-4:

J.R. Díaz Sánchez-Cid - El ser de Dios en el "Contra Celso" de Orígenes 5-44; J.J. Ayán Calvo - La „communio laica" del "Libellus precum» 439458; J.M. Magaz Fernández - El primado en la Iglesia medieval 483-502; C. Pozo - Los acontecimientos que condujeron a la celebración del Concilio de Éfeso (431), 503-516; E. Romero Pose - „De bono martyrii”. A propósito de los «Scorpiace» de Tertuliano 517-528.

163. REVISTA TEOLOGICĂ 12 (2002) nr 1-4:

I.M. Ielciu - Sf. Ioan Scărarul - omul şi opera 13-20. 
164. REVUE BÉNÉDICTINE 112 (2002) nr 1-4:

V. Skemp - Jerome's Tobit: A Reluctant Contribution to the Genre Rewritten Bible 5-35; J.P. Bouhot - Adaptations latines de l'Homélie de Jean Chrysostome sur Pierre et Élie (CPG 4513) (à suivre) 36-71; (suite et in) 201-235; D.J. Uitvlugt - The Sources of Isidore's «Commentaries on the Pentateuch» 72-100; M. Gorman - Alcuin before Migne 101-130; F. Dolbeau - À propos des sermons d'Olomouc: un postscriptum 236-245; M. Gorman - Source Marks and Chapter Divisions in Bede's "Commentary on Luke» 246-290; L.S.B. MacCoull - More Sources for the "Liber scintillarum» of Defensor of Ligugé 291-300; Y. Hen - Rome, Anglo-Saxon England and the Formation of the Frankish Liturgy 301-322.

165. REVUE DE L'HISTOIRE DES RELIGIONS 219 (2002) nr 1-4:

P. Boulhol - „Secta”: de la ligne de conduite au groupe hétérodoxe. Évolution sémantique jusquáu début du Moyen Âge 5-33; N. Ibrahim Fredrikson - La métaphore du sel et du serpent chez Aphraate, le Sage persan 3554; N. Pancer - Au-delà du sexe et du genre. L'indifférenciation des sexes en milieu monastique (VI $I^{e}-V I I^{e}$ siècles) 299-323; J.M. Roessle - Convergence et divergence dans l'interprétation du mythe d'Orphée. De Clément d'Alexandrie à Eusèbe de Césarée 503-513.

166. REVUE DES ÉTUDES AUGUSTINIENNES 48 (2002) nr 1-2:

$\mathrm{Ph}$. Bobichon - Autorités religieuses juives et "sectes" juives dans l'oeuvre de Justin Martyr 3-22; Y. Duval - La „plebs” chrétienne au ,siècle de Cyprien, jusqu'à la paix de l'Église (2) 23-41; (3) 43-78; A.D. Fitzgerald - Ambrose at the Well: "De Isaac et anima» 79-99; M.P. Bussieres - Les „questiones" 114 et 115 de l'Ambrosiaster ont-elles été influencées par l'apologétique de Tertullien? 101-130; P. Laurence - Juliana et Démétrias. Le christianisme des femmes de la „gens Anicia” dans la première moitié de $V^{e}$ siècle 131-163; M. Milhau - À propos de l'édition de la "Trinité» d'Hilaire de Poitiers 165-173; S. Deléani - Jean Philippe Royer (1928-2002), 225-228; G.D. Dunn - Cyprian and the Synod of Late 254, 229-247; N. Cipriani - „L'altro Agostino” di G. Lettieri 249-265; M. Dulaey - L'apprentissage de l'exégèse biblique par Augustin. (1) Dans les années 386-389, 267-295; N. Hecquet-Noti - Le corbeau nécrophage, figure du juif dans le "De diluvio mundi" d'Avit de Vienne: à propos de l'interprétation de Gn 8, 6-7 dans "Carm.» 4, 544-584, 297-320 ; I. Bouchet - Herméneutique, apologetique et philosophie. Recherches sur Augustin 321-329.

167. REVUE DES SCIENCES PHILOSOPHIQUES ET THÉOLOGIQUES 86 (2002) nr 1-4:

G.M. de Durand - Réflexions sur les quatre premiers conciles oecuméniques: Nicée (325), Constantinople (381), Éphèse (431), Chalcédoine (451), 3-26; G.M. de Durand - Sources et signification de Chalcédoine (451), 369$386 ; \mathrm{R}$. Wielockx - Incarnation et vision béatifique. Aperçus théologiques 
601-639 ; M. Pałuch - S. Augustin et S. Thomas. Le «De praedistinatione sanctorum" dans l'ocuvre de Thomas d'Aquin 641-647.

168. REVUE DES SCIENCES RELIGIEUSES 76 (2002) nr 1-3:

J.L. Feiertag - La crainte d'unc exploitation des ministères ccclésiaux en vue des profits personnels ct sa conséquence: l'idéal des ordinations imposées dans l'Église ancienne (I ${ }^{\prime T}-I V^{e}$ siècles) 161-184; M. Aoun - Aspects de la simonic en Egypte (VII'-XII' siècles) 185-200; Y. Meessen - Jamais l'un sans l'autrc. Une recherche sur l'intersubjectivité chez S. Augustin 426-446.

169. REVUE D'HISTOIRE DE L'ÉGLISE DE FRANCE 87 (2002) nr 218-219: M. Heijmans - Césaire d'Atles, un évêque et sa ville 5-25; H. Noizet - Les basiliques martyriales au $V I^{\prime}$ et au début du VII siécle 329-355.

170. REVUE D'HISTOIRE ET DE PHILOSOPHIE RELIGIEUSES 82 (2002) nr 1-4:

R. Roukema - La transcendance et la proximité de Dieu dans le christianisme ancien 15-31; M. Philonenko - „Les cieux et la terre obéiront à Son Messie" (4Q521, 2, II, 1 ct "Vie latine d'Adam et Ève» 29, 8) 115-122; M. Philoncnko - Adonaï, le Messie et le Saoshyant. Observations nouvelles sur 4Q521. 259-266; J.M. Pricur - L'éthique sexuelle et conjugale des chrétiens des premiers siècles et ses justifications 267-282.

171. REVUE THOMISTE 102 (2002) nr 3-4:

$\mathrm{H}$. Donneaud - Chaicédoinc contre l'unicité absolute du médiateur JésusChrist? 43-62; A. Patfoort - Emplois bibliques et patristiques du verbe kporeomai 63-72.

172. RHEINISCHES MUSEUM FÜR PHILOLOGIE 145 (2002) nr 1-4:

A. Coșkun - Symmachus, Ausonius und der ,senex olim Garumnae alumnus". Auf der Suche nach dem Adressaten von Symm. Epist. 9, 88, 120-128.

173. RICERCHE TEOLOGICHE 13 (2002) nr 1-2:

M.L. Rigato - Presenza viva e marginalizzazione della donna nella Chiesa romana delle origini 31-87; T. Giorgi - Ascesi ed esegesi nella Roma imperiale del IV secolo 89-97; A. Ballardini - Una speciale iconografia della veste: Agnese nel mosaico della basilica sulla via Nomentana 99-111.

174. RIVISTA BIBLICA 50 (2002) nr 1-4:

P. Artz-Grabner - „Brothers" and "Sisters” in Documentary Papyri and Early Christianity 185-204.

175. RIVISTA DI ARCHEOLOGIA CRISTIANA 78 (2002):

Ph. Pergola - Mgr Patrick Saint-Roch 1-11; G. Nestori - Bibliografia di Patrick Saint-Roch 13-17; F. Bisconti - Nuove idee per la lettura del programma decorativo del cubicolo A nell'ipogeo di via Dino Compagni 19-117; S. Burrafato - Due pitture con scene „paradisiche” nelle catacombe Siracusane 119-143; L. Dattrino - Giovanni Crisostomo di fronte al matrimonio 145-155; V. Fiocchi Nicolai - Santuario martiriale e territorio nella dioecesi di ,Nomentum": l'esempio di S. Alessandro 157-189; S. Heid 
- „Vexilium crucis”. Das Kreuz als Religions-, Missions- und Imperialsymbol in der Frühen Kirche 191-259; D. Mazzoleni - Un'iscrizione ritrovata: ICUR I 4007, 261-264; Ph. Pergola - Topographie chrétienne et établissement urbain dans les villes moyennes d'Italie du Nord: le cas d'"Aque Statielle" durant l'antiquité tardive et le haut moyen âge 265-299; A.M. Ramieri - Frammenti inediti di sarcofagi e di rilievi altomedievali da „via del Mare" in Roma 301-323; V. Saxer - Proposte e requisiti per la storia della celebrazione eucaristica in età tardo antica e alto medievale principalmente in Occidente 429-432.

176. RIVISTA DI TEOLOGIA. ASPRENAS 49 (2002) nr 1-4:

E. Albrile - San Gregorio e Mithra. Sincretismo iranico-mesopotamico nel cristianesimo armeno 163-190; G. Dal Maso - Sulla spiritualità della Chiesa armena 429-432; J.M. Mejía - Quale Pace? Testi biblici e patristici a confronto 483-492.

177. RIVISTA STORICA ITALIANA 114 (2002) nr 1-3:

A. Marcone - François Guizot e l'edizione francese della "History of the Decline and Fall of the Roman Empire" di Edward Gibbon 217-238; D. Vera - L. Cracco Ruggini - E. Fentress - A. Schiavone - C. Lepelley G.W. Bowersock - Antico e tardoantico oggi 349-379; A. Marcone - La peste antonina. testimonianze e interpretazioni 803-819; L. Cracco Luggini - L'ordine naturale sconvolto e la morte di un mondo nella storiografia tardoantica 820-850; A. Marcone - Il sacco di Roma del 410 nella riflessione di Agostino e di Orosio 851-867; G. Zecchini - Attila. Una figura epocale? 868-879.

178. ROCZNIK TEOLOGICZNY 44 (2002) nr 1-2:

(Nr 2) J. Przybył - Celtyckie chrześcijaństwo - prawda i mistyfikacja 53-67; D. Sawicki - Historia Prawostawnego Patriarchatu Butgarskiego 83-105.

179. ROCZNIKI HUMANISTYCZNE 50 (2002) z. 4 (Historia Sztuki):

A. Frejlich - Hagiografia bizantyńska jako źródto do dziejów ikony zagadnienia wybrane 23-35.

180. ROCZNIKI TEOLOGICZNE WARSZAWSKO-PRASKIE 2 (2002):

J. Krykowski - Homilia 12 sw. Jana Chryzostoma na List do Kolosan, wprowadzenie i przektad 39-60; K. Obrycki - Odpowiedź św. Augustyna na memoriat Orozjusza w sprawie btędów pryscylian i orygenistów 143-170.

181. ROCZNIK TEOLOGII KATOLICKIEJ 1 (2002):

P. Martyniuk - Duchowość Wschodu 53-63.

182. ROMISCHE QUARTALSCHRIFT 97 (2002) nr 1-4:

M.B. von Stritzky - Schriftauslegung als Verkündigung. Phil. 2, 6-7 in den Weihnachtspredigten Leos des Großen 1-16; P. Grossmann - Frühchristliche Kirchen im Gebiet des Ammon-Tempels von Luqsur 17-39; S. Diefenbach Beobachtungen zum antiken Rom im hohen Mittelalter: Städtische Topographie als Herrschafts- und Erinnerungsraum 40-88; P. Engelbert - Bischö- 
fe und Klöster im Frühmittelalter 161-193; H. Flachenecker - Heilige Bischöfe als einheitsstiftende Klammer für mittelalterliche Diözesen 194-214.

183. SACRA DOCTRINA 47 (2002) nr 1-6:

(Nr 1) A. Carpin - Elementi di ecclesiologia isidoriana 5- 54; A. CarpinL'esperienza battesimale di san Cipriano 81-131.

184. SAECULUM 53 (2002) nr 1-2:

W. Drews - Goten und Römer als Gegenstand der Historographie bei Isidor von Sevilla 1-20.

185. SALESIANUM 64 (2002) nr 1-4:

M. Marin - L'unità del mondo visibile secondo Plotino (II parte) 7-28;

M. Amerise - L'idea di misericordia tra paganesimo tardoantico e cristianesimo: il caso di Giuliano l'apostata 221-229; D. de Pablo Maroto - La "Lectio Divina". Praxis histórica y pastoral 433-462.

186. SALMANTICENSIS 49 (2002) nr 1-3:

R. Trevijano Etcheverría - Bibliografía patrística hispano-lusoamericana, XII (1999-2000) 137-196.

187. SALVATORIS MATER 4 (2002) nr 1-3:

(Nr 1) B. Kochaniewicz - Dziewictwo Boga-dziewictwo Maryi w ujęciu niektórych Ojców Kościota 102-116; D. Kaliński - Dziewictwo Maryi w tradycji Kościola Wschodu i Zachodu 117-134; (nr 3) W. Misztal Wiara w pośrednictwo Maryi oraz jej kult w duchowości pierwszych chrześcijan 232-251.

188. SAPIENZA 55 (2002) nr 1-4:

G. Balido - Agostino in Whitehead? 89-105; K. Sakellariou - F. Fiorentino - La formazione del corpo umano secondo Gregorio di Nissa (379 d.C) 295-305; B. Mondin - La bellezza come transcendentale in Platone, Agostino e Tommaso 385-397.

189. SCOTISH JOURNAL OF THEOLOGY 55 (2002) $\mathrm{nr} 1-4$ :

K.B. McCruden - Monarchy and economy in Tertullian's "Adversus Praxean" 325-237.

190. LA SCUOLA CATTOLICA 130 (2002) nr 1-4:

P. Caramassi - „Qualiter beatus Ambrosius libros Veteris Testamenti et Novi ad legendum ecclesiae disposuisset". Il lezionario della Chiesa milanese tra età tardo antica e medioevale 837-879.

191. SEMINARE 18 (2002):

G.M. Bartosik - Kult Maryi w liturgii bizantyjskiej 67-83; T. Kołosowski Lektura Pisma św. w „duchu” w świetle «Commentarius in Mathaei Evangelium» biskupa Hilarego z Poitiers 513-525.

192. ST. VLADIMIR'S THEOLOGICAL QUARTERLY 46 (2002) nr 1-4:

J. Hainswort - The Force of the Mystery: Anamnesis and Exegesis in Melito's "Peri Pascha» 107-146; D.F. Stramara - Surveying the Heavens: Early Christian Writers on Astronomy 147-162; A. Golitzin - Dionysius the 
Areopagite in the Works of Gregory Palamas: On the Question of a "Christological Corrective" and Related Matters 163-190; G. Metallidis - Theodore of Studium against the Iconoclasts: The Arguments of His Letters 191-208; R.M. Haddad - The Stations of the Filioque 209-268.

193. STORIA DELLA STORIOGRAFIA 21 (2002) nr 41:

P. Payen - L'historién, la guerre, l'écriture, les vaincus (Vìme siècle avant J.-C. - II ime siècle après J.-C.) 45-70.

194. STUDI ITALIANI DI FILOLOGIA CLASSICA 95 (2002) t. 20, nr 1-2: G. Massimilla - Contributi interpretativi alle "Dionisiache» di Nonno 206216; N. Pace - Le citazioni non identificate comprese nella parte $A-H$ del "Lexicon Ambrosianum»" 217-241.

195. STUDIA ANSELMIANA 1.34 (2002):

A. Kemmer - Cristo nella "Regola» di san Benedetto 89-104; A. Mundó L'autenticità della "Regula Sancti Benedicti» 105-162; A. Kemmer - Cristo nella "Regola» di san Benedetto 89-102: A. Mundó - L'autenticità della "Regula» Sancti Benedicti 105-160; B. Stcidle - La promessa della "stabilita", della „conversatio morum" e dell" obbedienza" nella "Regola» di S. Benedetto 163-186: G. Turbessi - La "Regola" di san Benedetto nel contesto delle antiche regole monastiche 189-230; $\mathrm{B}$. Calati - L'interpretazione della "Regola» 233-249; K. Hallinger - ,Consuetudo": concetto, forme, storia della ricerca, contenuto 251-283: P. Engclbert - Percorsi di storia benedettina: fra "Regola» e riforma 285-308; G. Penco - Il concetto di "spiritualità benedettina" nelle riflessioni storico-dottrinali dell'epoca contemporanea 357-382: J. Gribomont - San Basilio nella grande tradizione benedettina 385-411: A. De Vogué - Venticinque anni di ermeneutica benedettina. Un esame di coscienza 413-463; A. Wathen - Considerazioni metodologiche sulle fonti della "Regola» benedettina quale strumento di interpretazione storica 465-487; B. Studer - La Schola Christi nella "Regola» di san Benedetto 489-508; J. Leroy - San Benedetto nel mondo bizantino 511-525.

196. STUDIA BOBOLANUM 2 (2002) nr 1-3:

(Nr 2) M. Blaza - Proklamacja Stowa Bożego w bizantyńskiej tradycji liturgicznej 131-155: (nr 3) H. Pictras - Od prezbiteratu do kaptaństwa: ewolucja pojęć i urzędu 5-17.

197. STUDIA GNESNENSIA 16 (2002):

Sz. Pieszczoch - Patrystyczne podtoże rozwoju wiary w macierzyństwie dziatania Maryi dla Kościola i ludzkości 105-125; B. Hrab - Bibliografia zawartości rocznika "Studia Gnesnensia" za lata 1975-2001, 331-359 (patrologia: 334-335).

198. STUDIA LAURENTIANA $2(200) 2) \mathrm{nr} 1$ :

D. Kasprzak - Czy sw. Augustyn byt filozofem? 7-28; M. Wojewoda Problem wiary $i$ rozumu "Augustyna $i$ Bonawentury na tle filozofii 
wspótczesnej 29-48; J. Dębski - Pubblicazioni di Padre Raniero Cantalamessa OFMCap - predicatore della Casa Pontificia (anni 1960-1999) 137. 163.

199. STUDIA LOVICIENSIA 4 (2002):

J. Krykowski - Le nozioni di ,conversio" $e$,conversatio" nell'insegnamento penitentziale di Cipriano di Cartagine 47-52.

200. STUDIA MONASTICA 44 (2002) nr 1-2:

A. de Vogüé - Un problème de datation: La Règle des Quatre Pères 7-11; A. Golitzin - „The Demons suggest an Illusion of God's Glory in a Form”: Controversy over the Divine Body and Vision of Glory 13-43; S. Salvestroni - Isacco il Siro e l'Opera di Dostoevskij 45-56; A. Casiday - „All are from one": on St. Anthony the Great's Protology 207-227; G. Penco Caratteri ed obiettivi della storiografia monastica italiana contemporanea 229-238; T. Vivian - N. Athanassakis - Montanism, Heresy, or ProtoMonasticism? The Martyrdom of St. Theodotos of Ancyra and of the seven Virgins with Him 239-292.

201. STUDIA PELPLIŃSKIE (2002) t. 32 i 33 (wyd. specjalne):

(Nr 33) F. Drączkowski - Rodzaje świadczenia Chrystusowi w nauce Klemensa Aleksandryjskiego 209-218; D. Drążek - Dwa kazania św. Maksyma z Turynu o św. Wawrzyńcu na tle starożytnej tradycji o tym rzymskim męczenniku 219-227; A. Eckmann - Przebóstwienie czlowieka w pismach św. Augustyna. Pojęcia i określenia 245-264.

202. STUDIA PŁOCKIE 30 (2002):

W. Turek, „Nie ma władzy, która by nie pochodziła od Boga”. Rz 13, 1 $w$ interpretacji Ireneusza i Orygenesa 53-64; M. Zahajkiewicz - Średniowieczna teoria misji 65-72; L. Misiarczyk - Smutek i gniew w nauce duchowej Ewagriusza z Pontu 83-96.

203. STUDIA SANDOMIERSKIE 9 (2002):

W. Przygoda - Znaczenie posługi charytatywnej Kościoła w świetle Ewangelii i świadectwa starożytności chrześcijańskiej 185-200.

204. STUDIA TEOLOGICZNE BIAŁYSTOK - DROHICZYN - ŁOMŻA 20 (2002):

M. Ozorowski - Cele matżeństwa w nauczaniu teologów średniowiecza 87101; R. Klimsza - Od obrazu do podobieństwa. Osoba ludzka - podmiot duchowości w tradycji chrześcijańskiego Wschodu 267-278; R. Szmurło Krótki zarys historii języka i piśmiennictwa koptyjskiego 327-336.

205. STUDIA THEOLOGICA (NOR) 56 (2002) nr 1-2:

O. Leirvik - History as a Literary Weapon: The "Gospel of Barnabas» in Muslim-Christian Polemics 4-26.

206. STUDIA WARMIŃSKIE 39 (2002):

A. Miotk - „Peregrinatio pro Christi amore” we wczesnym średniowieczu 161-168. 
207. STUDIA WŁOCŁAWSKIE 5 (2002):

T. Kaczmarek - Symbolika chrzcielna w nauczaniu Kościoła starożytnego 137-149.

208. ŚLĄSKIE STUDIA HISTORYCZNO-TEOLOGICZNE 35 (2002) nr 1-2: Apokryf Jana, wstęp i tłum. W. Myszor (z koptyjskiej wersji NHC II 1), 73-89; A. Uciecha - Ideat bezżeństwa „Synów Przymierza” bnay qyāmā w polemice z judaizmem w «Mowach" Afrahata 90-103; R. Nakonieczny Zagadnienie mowy w traktatach deontologicznych Cycerona i św. Ambrożego 271-292; R. Szmurło - Śmierć Maniego (fragmenty III "Homilii manichejskiej»). Wstęp, komentarz i tlum. z języka koptyjskiego 291-297.

209. TARNOWSKIE STUDIA TEOLOGICZNE 21 (2002) nr 1-2:

A. Żurek - Prawo duszpasterzy do „życia z Ewangelii” w świetle tradycji patrystycznej 97-117.

210. TEOLOGIA Y VIDA 43 (2002) nr 1-3:

A.G. Arbea - El centón homérico de Eudoxia (s. $V$ d. C.) 97-106; G.B. Burlando - Pensamientos eternos: Platonismos de Agustín y Frege 107-120; J.D. Busquéis - Recepción de Agustín en el pensamiento de Lutero 121-137; A.F. Castellano - Juan 6 en la interpretación de Orígenes (I ${ }^{a}$ Parte) 138-166; P.A.C. de Ciner - Aproximación al éxtasis en Plotino y Origenes 167-174; M. Correia - Libertad humana y presciencia divina en Boecio 175-186; A.C. Covarrubias - Lenguaje, belleza y verdad en Cicerón y San Agustín: las encrucijadas de la persuasión 187-195; L. Dattrino - Gen 1, 26-27 e Gen 2, 7 nella interpretazione patristica (le scuole „asiática” $e$ „alessandrina”) 196204; H.R. Drobner - Fuentes y métodos filosóficos de Gregorio de Nisa 205215; S.E. Fernández - El debate teológico público y oral en la Iglesia prenicena 216-227; F.J. Fortuny - Juan Escoto Eriúgena: Subjetividad divina y teología negativa 228-250; F. García Bazán - En los comienzos de la filosofía cristiana: La actitud de los escritores eclesiásticos y de los gnósticos ante la filosofía 251-268; S. Magnavacca - El pasaje de XI, 29, 39 en la estructura de las "Confessiones» 269-284; A.W. Meis - El significado teológico de la frase "El conocimiento se convierte en amor". (De an et res, PG 46, 96. 37) de Gregorio de Nisa y su recepción por Guillermo de Saint Thierry 285-302; J. M. Nieva - Ejercicios espirituales y trascendencia en Dionisio Areopagita 303-309; J.A.Z. Pachas - Significado teológico del término ftápit; en el "In Inscriptiones Psalmorum» de Gregorio de Nisa 310318; H.J.J. Padrón - Una estética del icono en el pensamiento de San Agustín 319-329; C. Pierantoni-Dios y la materia: Propuesta a partir del Timeo de Platón y las "Confesiones» de San Agustín 330-342; E.G. Reyes - La reciprocidad. Algunas reflexiones a partir de las "Homilias» I a IV de Gregorio de Nisa 343-349; G.L.G. de Ritacco - Los himnos theárquicos 350-376; R.E. Trevijano - La Plenitudo Temporis (Gal 4, 4): Interpretaciones de Orígenes 377-396; O. Velásquez - La creación como retorno al 
Creador en "Confessiones» XI-XIII, 397-402; M.T.R. Viviani - Comunidades cristianas al este del Jordán. Un análisis arquitectónico (S. I-VI D. C.) 403-435; S.U. Zañartu - Presentación de algunos aspectos de la Trinidad en los discursos teológicos de Gregorio de Nacianzo 436-464.

211. TERMINUS 4 (2002) z. 1-2:

$\mathrm{H}$. Chadwick - Milczenie biskupów u św. Ignacego, tłum. K. Bielawski 143-148; K. Bielawski - Niespetniony testament? Uwagi do dziejów relikwii św. Ignacego Męczennika 149-155.

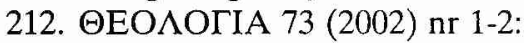

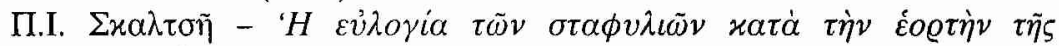

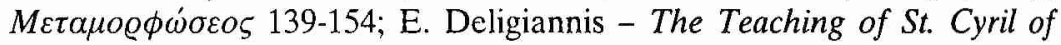
Alexandria on the resurrection of Jesus Christ according to his addresses to the princesses 305-318; M. Marioras - L'Institution du Synode de Provin-

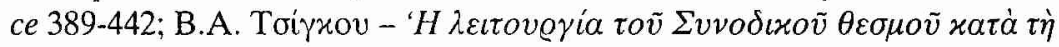

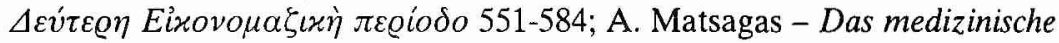

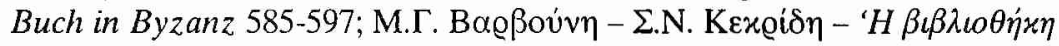

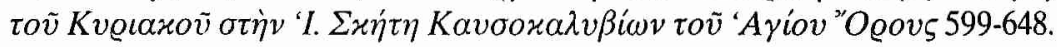
H.J. Sieben - Israels Wiistenwanderung (Num 33) in der Auslegung des Hieronymus und des Origenes. Ein Beitrag zur Geschichte der Spiritualität und der origenistischen Streitigkeiten 1-22.

213. THEOLOGY DIGEST 49 (2002) nr 1-4:

M.A. Vannier - Clarification on the "filioque" 21-28; A. Viciano - The Church Fathers and modern theology 139-143.

214. THEOLOGY TODAY 59 (2002) nr 1-4:

G. McCullough - Heidegger, Augustine, and „Poiessis”: Renewing the Technological Mind 21-38.

215. THEOTOKOS 10 (2002) nr 1:

E. Dal Covolo - La dottrina mariana di Tertulliano 17-31; M.G. Bianco Riferimenti mariani in Clemente Alessandrino 33-42; M.I. Danieli - Maria "Terra di profeti viventi". Profezie mariane in Origene 43-52; R. Scognamiglio - La fisionomia „teologica” di Maria. Maternità et virginità 53-69; F. Cocchini-Maria ,modello del cristiano" nell'interpretazione origeniana 71-85.

216. LA TRADITON MANUSCRITE EN ÉCRITURE ARABE (2001) nr 99-100:

J. Grand'Henry - Contribution à l'histoire du texte de la version arabe du «Discours» 40 de Grégoire de Nazianze 157-167.

217. TRIERER THEOLOGISCHE ZEITSCHRIFT 111 (2002) nr 1-4: M. Fiedorowicz - Die Rezeption und Interpretation der paulinischen Areopag-Rede in den patristischen Theologia 85-105; H. Heinen - Überfülte Kirchen. Bischof Athanasius ïber den Kirchenbau in Alexandrien, Trier und Aquileia 194-211. 
218. UNA SANCTA 57 (2002) nr 1-4:

E.Ch. Suttner - Vorchalcedonische und chalcedonische Christologie: die eine Wahrheit in unterschiedlicher Begrifflichkeit 6-15; G. Wenz - Chalcedon 451: Wahrer Mensch und waltrer Gott 16-30; P. Neuner-Spaltung und Versöhnung: Zur ökumenischen Relevanz des Chalcedonense 31-45; K. Pinggéra - Kommunitäres Leben als Herausforderung für die Kirche: Basilius der Große und Dietrich Bonhoeffer 246-256.

219. VERBUM VITAE (2002) nr 1-2:

(Nr 1) K. Bardski - Chrystus jako Zbawiciel w alegoryczno-symbolicznej interpretacji epizodu o uciszeniu burzy (Mt 8, 23-27; Mk 4,35-5, 1; $E k$ 8, 22-26), 201-226; T. Gacia - „Przyodziej ciata trofeum...”. Soteriologia hymnów św. Ambrozego 227-251; J. Pałucki - Jezus jako Zbawiciel w nauczaniu Paulina z Noli 253-269; (nr 2) K. Bardski - „Daj mi ustyszeć twój głos!" Wezwanie do zwiastowania Ewangelii w wybranych alegoriach „Pieśni nad Pieśniami”, 225-241; L. Nieścior - Psalmy w procesie wewnętrznej ewangelizacji chrześcijanina 243-251; J. Naumowicz - Orzech i laska Aarona, czyli zgtębianie i głoszenie Słowa Bożego w ujęciu Ojców Kościoła 253-266.

220. VERITAS 47 (2002) nr 1-4:

B. Silva Santos - $A$ metafísica da memoriá no livro $X$ das "Confisses" de Agostinho 365-375; J. Martíney Barrera - Nota sobre el augustinismo politico 377-385; A. Fidora - On the supposed "Augustinisme avicennisant" of Dominicus Gundissalinus 387-394.

221. VERKÜNDIGUNG UND FORSCHUNG 47 (2002) nr 1-2:

(Nr 2) R. Leeb - Die Konstantinische Wende 4-27; K. Fitschen - Von der Spätantike zum Mittelalter 27-48.

222. VETERA CHRISTIANORUM 39 (2002) nr 1:

M. Simonetti - Ricerca patristica e promozione degli studi cristianistici in Antonio Quacquarelli 5-17; G. Otranto - L'attività di Antonio Quacquarelli tra ricerca e impegno per il territorio 19-33; C. Carletti - "Domine Eutychi". Un culto ritrovato' nell area cimiteriale di s. Sebastiano a Roma 35-33; F. Grelle - Il titolo „De paganis sacrificiis et templis” nel Codice di Giustiniano 61-67; I. Aulisa - La polemica antigiudaica agli inizi del $V$ secolo in due scritti anonimi 69-100; L. Carnevale - Esegesi etterale e metafora: da Tommaso d'Aquino alla scuola antiochena 101-114; L. Arcari - Apocalisse di Giovanni e apocalittica ,danie-lico-storica” del I sec. e.v. prospettive per una 'nuova' ipotesi 115-132; G. Volpe et alii - Il complesso episcopale paleocristiano di san Pietro a Canosa. Prima relazione preliminare (campagna di scavi 2001) 133-190; L'esegesi patristica in Italia: bilancio e prospettive di un'esperienza formativa (Troni, 6-8 giugno 2002) 191-196.

223. VIA CONSECRATA 5 (2002) nr 1-12:

L. Pawlak - Brat-mnich 28-33. 
224. VIGILIAE CHRISTIANAE 56 (2002) nr 1-4:

J. Ysebaert - The So-Called Coptic Ointment Prayer of «Didache»10, 8

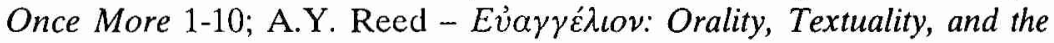
Christian Truth in Irenaeus' "Adversus Haereses» 11-46; G.D. Dunn Rhetorical Structure in Tertullian's "Ad Scapulam» 47-55; E. Carotenuto - Six Constantinian Documents (Eus. HE 10, 5-7), 56-74; W. Löhr - Some Observations on Karl-Heinz Schwarte's 'Diokletian's Christengesetz' 7595; A. Stewart-Sykes - Rites and Patronage Systems in Third-Century Africa 115-130; P. Van Nuffelen - Deux fausses lettres de Julien l'Apostat (La lettre aux juifs, Ep. 51 Wright), et la lettre à Arsacius, Ep. 84 (Bidez), 131-150; H. Schneider - Das Ibis-Kapitel im "Physiologus» 151-164; J.C.M. Van Winden - Apocabatur 165-166; A.D. Deconick - The Original «Gospel of Thomas» 167-199; H. Van De Sandt - 'Do not Give what is Holy to the Dogs' (Did 9:5D and Matt 7:6A): The eucharistie food of the "Didache» in its Jewish purity setting 223-246; A. M. Silvas - Edessa to Cassino: The Passage of Basil's "Asketikon» to the West 247-259; T. Nicklas - Ein "Neutestamentliches Apokryphon"? Zum umstrittenen Kanonbezug des sog. „Petrusevangeliums” 260-272; A. P. Bos - 'Aristotelian' and 'Platonic' Dualism in Hellenistic and Early Christian Philosophy and in Gnosticism 273-291; Th. G. Sinnige - Plotinus on the Human Person and its Cosnic' Identity 292-295; E. Pagels - Irenaeus, the "Canon of Truth" and the "Gospel of John": "Making a Difference” through Hermeneutics and Ritual 339-371; R. Cross - Gregory of Nyssa on Universals 372-410; C. Leonhard - Sürat Ktāb. Bemerkungen zum sogenannten „Rituale” des Theodor von Mopsuestia am Beginn der Katechetischen Homilien 12-16, 411-433; V. Buchheit - Göttlicher Heilsplan bei Paulinus von Nola (c. 22), 434-438.

225. VITA MONASTICA 56 (2002) nr 220-222:

Th. Matus - Monachesimo e inculturazione. Bruno di Querfurt (1009) tra Gregorio Magno (604) e Jules Monchanin ( + 1957), 29-47.

226. VIVENS HOMO 13 (2002) nr 1-2:

C. Nardi - Eros. Patristica e oltre 129-142; C. Nardi - Eros: coazione a ripetere o dono gioioso: Patristica tra mito e logos 229-257.

227. VOX LATINA 38 (2002) nr 147-150:

G. Licoppe - De itinere Syriaco (II) 30-35; 224-232; C. Eichenseer - De festiva nive corusca festi Nativitatis Dominicae 70-81; S. Albert - De Constantini Magni conceptione imperiali deque conditione Constantinopolis 346-361; Aurelius Augustinus - Homilia natalicia (Sermo 190, PL 38, 1007-1009) 4470-472.

228. W DRODZE (2002) nr 1-12:

(Nr 11) M. Zioło - Jak czytać Regułę (o regule Benedykta) 69-75; (nr 12) M. Zioło - O milczeniu (o regule Benedykta) 77-82. 
229. WARSZAWSKIE STUDIA TEOLOGICZNE 15 (2000):

K. Jażdżewska - O pochodzeniu „Fizjologa” 85-100; M.M. López García La autobiografica de san Justino y elementos autobiográficos de Taciano 101-120; T. Stępień - Czystość serca a poznanie prawdy. Pseudo-Dionizy Areopagita $i$ św. Augustyn wobec filozoficznej nauki o czystości 121-132; J. Naumowicz - Chrześcijańska rachuba czasu. Refleksje na poczq̨ek III tysiąclecia 133-140; M. Starowieyski - Ks. prof. Józef Bilczewski-uczony 141-156.

230. ВЕСТНИК РУССКОГО ХРИСТИАНСКО ПОДВИЖЕНИЯ (2002) nr 182-184:

(Nr 184) В. Никитин - К антропологии Августина 114-135.

231.WIADOMOSCI DIECEZJALNE SIEDLECKIE 70 (2001) nr 1-12:

S. Jaśkiewicz - Semantyka terminu „morze" w kontekście "Hexaemeronu» św. Ambrożego 311-421.

232. WISSENSCHAFT UND WEISHEIT 65 (2002) nr 1:

Ch. Göbel - Philosophie des Mönchseins. Am Beispiel des «Ad Monachos» des Evagrius Ponticus und seines Bezeuges zum ,asketischen" Charakter der antiken Ethik 3-23; M. Enders - Die Regel des heiligen Augustinus - ihr gedanklicher Aufbau und ihre Lehre vom Prinzip des monastischen Lebens 24-61

233. WORSHIP 76 (2002) nr 1-6:

C.R. Hutcheon - The "Euchelaion» - Mystery of Restoration: Anointing in the Byzantine Tradition 25-42.

234. ZAWSZE WIERNI (2002) nr 1 i 5:

(Nr 1) E. Hello - Oblicza świętych. Św. Jan Chryzostom 124-134; (nr 5) D.E. Madejski - Zbrodnicza „superstitio". Dzieje konfliktu między państwem rzymskim a chrześcijańskim do pot. IV wieku po Chrystusie 4-22.

235. ZEITSCHRIFT FÜR ANTIKES CHRISTENTUM 6 (2002) nr 1-2:

F.R. Prostmeier - Antijudaismus im Rahmen christlicher Hermeneutik. Zum Streit über christliche Identität in der Alten Kirche. Notizen zum Barnabasbrief 38-58; H.J. Vogt - Noet von Smyrna und Heraklit. Bemerkungen zur Darstellung ihren Lehren durch Hippolyt 59-80; W. Pradels Lesbos Cod. Gr.27: The Tale of a Discovery 81-89; W. Pradels - R. Brändle - M. Heimgartner - The Sequence and Dating of the Series of John Chrysostom's Eight Discourses "Adversus Iudaeos» 90-116; P. Lampe - The Phrygian Archeological Surface Survey Project of the University of Heidelberg and the Discovery of Pepouza and Tymion. A preliminary report 117-120; T. Krannich - Ch. Schubert - Väterzitate im Horos der ikonoklastischen Synod von Hiereia (754 n. Chr.) 121-124; D. Weber Dritter Bericht über lateinische Editionen und Hilfsmittel aus dem Gebiet der Patristik 215-231; H.G. Bethge - U.U. Kaiser - U.K. Plisch - Bericht über Editionen von koptischen Texten und Publikationen von Hilfsmitteln 
232-252; N. Lenski - Were Valentinian, Valens and Iovian Confessors bevor Julian the Apostate? 253-276; F. Witek - „Nunc clarius, nunc pressius". Physikalische und theologische Implikationen in Aurelius Augustinus' Schrift «De ordine» 277-298; V. Heil - „... blo nicht wie die Manichäer!". Ein Vorschlag zu der Hintergründen des arianischen Streits 299. 319; K. Schäferdick - Der vermeintliche Arianismus der Ulfila-Bibel. Zum Umgang mit einem Stereotyp 320-329; G.D. Dunn - Eusebius von Emesa und die Juden. Tertullian and Daniel 9, 24-27. A Patristic Interpretation of a Prophetic Time-Frame 330-344; K. Metzler - „Nimm und lies” 345-347; M. Wallraff - Patristische Arbeitshilfen in Internet (IV). Datenbanken und e-Texte 348-352.

236. ZEITSCHRIFT FÜR KATHOLISCHE THEOLOGIE 124 (2002) nr 1-4: B. Kriegbaum - Die Donatistische Konzilien von Cebarussa (393) und Bagai (394), 278-293.

237. ZEITSCHRIFT FÜR LITERATURWISSENSCHFT UND LINGUISTIK 32 (2002) nr 125-128:

(Nr 126) B. Jussen - „Confessio”. Semantische Beobachtungen in der lateinischen christlichen Traktatliteratur der Patristik und des 12. Jahrhunderts 27-47.

238. ZEITSCHRIFT FÜR MISSIONSWISSENSCHAFT UND RELIGIONSWISSENSCHAFT 86 (2002) nr 1-4:

H.J. Klauck - Die antiken Mysterienkulte und das Urchristentum - Anknüpfung und Widerspruch 3-25; J. Spiegl - Zur apologetischen und antihäretischen Ausrichtung des Religionsbegriffes Augustinus 26-43

239. ZEITSCHRIFT FÜR NEUES TESTAMENT 5 (2002) nr 10:

U. Berner - W. Stegemann - War das frühe Christentum eine Religion? Einführung K. Erlemann 53-68.

240. ZEITSCHRIFT FÜR PHILOSOPHISCHE FORSCHUNG 56 (2002) nr 1-4:

J. Halfwassen - Sein als uneingeschränkte Fülle. Zur Vorgeschichte des ontologischen Gottesbeweises im antiken Platonismus 497-516.

241. ZEITSCHRIFT FÜR RELIGIONS- UND GEISTESGESCHICHTE 54 (2002) nr 1-4:

I. Kalimi - „... und Josef verleumdete seine Brüder”. Josef Verrat in den Midraschim als Beitrag zur zeitgenössischen jüdisch-christlichen Kontroverse 23-31.

242. ZESZYTY FORMACJI DUCHOWEJ (2002) nr 18-20:

(Nr 20) M. Raczkiewicz - Wybór szczęścia według Ojców Kościoła 1826.

243. ZESZYTY FORMACJI KATECHETÓW 2 (2002) nr 1-4:

(Nr 2) E. Falińska - Osobowość dobrego katechety wedtug św. Augustyna na podstawie "De catechizandis rudibus» 20-22. 
244. ZESZYTY KARMELITAŃSKIE (2002) nr 1-4:

(Nr 1) M. Jekel - Człowiek średniowiecza wobec ubóstwa, czyli o roli jatmużny w życiu chrześcijanina 10-18.

245. ZESZYTY MARYJNE 5 (2001) nr 1-6:

(Nr 1) Ojciec Bruno - Obrońca dziewictwa Maryi (św. Hieronim) 14-15; (nr 2) Ojciec Bruno - Matka wszystkich wyznawców Chrystusa (św. Augustyn) 17-20; (nr 3) Ojcicc Bruno - Święta Matka naszego Pana (św. Ambroży) 15-17; (nr 4) Ojciec Bruno - Obrońca Jezusa, prawdziwego Syna Boga i Maryi (św. Hilary) 15-16; (nr 5) J. Kumala - Maryja-Matka Chrystusa, prawdziwego Boga i prawdziwego czlowieka (sw. Leon Wielki) 16-18; (nr 6) J. Kumala - Maryja zrodziła Stwórcę wszechświata (św. Fulgencjusz z Ruspe) 14-15.

246. ZESZYTY PRAWNICZE 2 (2002) nr 1:

Z. Służewska - Prawo rzymskie $w$ internecie 141-158.

247. ZNAK 54 (2002) nr 1-12:

(Nr 11) H. Pietras - Postrzeganie kaptaństwa 94-104.

zebrał

Józef Figiel SDS - Lublin, KUL 